\title{
Determining the influence of environmental and edaphic factors on the fate of the nitrification inhibitors DCD and DMPP in soil
}

Guardia, Guillermo; Marsden, Karina; Vallejo, Antonio; Jones, David; Chadwick, David

\section{Science of the Total Environment}

DOI:

10.1016/j.scitotenv.2017.12.250

Published: 15/05/2018

Peer reviewed version

Cyswllt i'r cyhoeddiad / Link to publication

Dyfyniad o'r fersiwn a gyhoeddwyd / Citation for published version (APA):

Guardia, G., Marsden, K., Vallejo, A., Jones, D., \& Chadwick, D. (2018). Determining the influence of environmental and edaphic factors on the fate of the nitrification inhibitors DCD and DMPP in soil. Science of the Total Environment, 624, 1202-1212.

https://doi.org/10.1016/j.scitotenv.2017.12.250

\footnotetext{
Hawliau Cyffredinol / General rights

Copyright and moral rights for the publications made accessible in the public portal are retained by the authors and/or other copyright owners and it is a condition of accessing publications that users recognise and abide by the legal requirements associated with these rights.

- Users may download and print one copy of any publication from the public portal for the purpose of private study or research.

- You may not further distribute the material or use it for any profit-making activity or commercial gain

- You may freely distribute the URL identifying the publication in the public portal ?
}

Take down policy

If you believe that this document breaches copyright please contact us providing details, and we will remove access to the work immediately and investigate your claim. 
1 Determining the influence of environmental and edaphic factors on the fate of the 2 nitrification inhibitors DCD and DMPP in soil

3 Guillermo Guardia ${ }^{1}$, Karina A. Marsden ${ }^{2}$, Antonio Vallejo ${ }^{1}$, Davey L. Jones ${ }^{2}$, David R.

4 Chadwick $^{2}$.

$5{ }^{1}$ ETSI Agronómica, Alimentaria y de Biosistemas (ETSIAAB), Universidad Politécnica de Madrid

6 (UPM), Ciudad Universitaria, 28040 Madrid, Spain.

$7 \quad{ }^{2}$ School of Environment, Natural Resources and Geography, Bangor University, Bangor, Gwynedd LL57

$82 \mathrm{UW}, \mathrm{UK}$.

$9 \quad *$ Corresponding author. Tf. +34 913365644. e-mail: guillermo.guardia@ upm.es

10 Abstract

11 Nitrification inhibitors (NIs) such as dicyandiamide (DCD) and 3,4-dimethylpyrazole 12 phosphate (DMPP) provide an opportunity to reduce losses of reactive nitrogen $(\mathrm{Nr})$ 13 from agricultural ecosystems. To understand the fate and efficacy of these two 14 inhibitors, laboratory-scale experiments were conducted with ${ }^{14} \mathrm{C}$-labelled DCD and DMPP to determine the relative rates of mineralization, recovery in soil extracts and sorption in two agricultural soils with contrasting $\mathrm{pH}$ and organic matter content.

17 Concurrently, the net production of soil ammonium and nitrate in soil were determined.

18 Two months after NI addition to soil, significantly greater mineralization of ${ }^{14} \mathrm{C}$-DMPP $19(15.3 \%)$ was observed, relative to that of ${ }^{14} \mathrm{C}-\mathrm{DCD}(10.7 \%)$, and the mineralization of both NIs increased with temperature, regardless of NI and soil type. However, the mineralization of NIs did not appear to have a major influence on their inhibitory effect (as shown by the low mineralization rates and the divergent average half-lives for mineralization and nitrification, which were 454 and 37 days, respectively). The nitrification inhibition efficacy of DMPP was more dependent on soil type than that of 
DCD, although the efficacy of both inhibitors was lower in the more alkaline, loworganic matter soil. Although a greater proportion of DMPP becomes unavailable, possibly due to physico-chemical sorption to soil or microbial immobilization, our results demonstrate the potential of DMPP to achieve higher inhibition rates than DCD in grassland soils. Greater consideration of the interactions between NI type, soil and temperature is required to provide robust and cost-effective advice to farmers on NI use.

Keywords: Fertilizer use efficiency; Nutrient cycling; Nitrogen losses; ${ }^{14} \mathrm{C}$-isotope; NI mineralization; NI sorption.

\section{Highlights:}

- DCD and DMPP mineralization was slow and did not affect their nitrification inhibition efficacy.

- Relative to DCD, less DMPP was sorbed to the solid phase and more was mineralized.

- Inhibition efficacy of DCD and particularly DMPP decreased in the calcareous soil.

- Both DCD and DMPP mineralization and inhibition efficacy were strongly influenced by temperature.

\section{Introduction}

Nitrification inhibitors (NIs) offer the potential to decrease reactive nitrogen (Nr) losses, which occur when large quantities of ammonium $\left[\mathrm{NH}_{4}{ }^{+}\right]$based fertilizers or urea are applied to agricultural soils. The $\mathrm{NH}_{4}{ }^{+}$present in the soil can be oxidized to nitrate $\left(\mathrm{NO}_{3}{ }^{-}\right)$through nitrification, a biotic process which occurs under aerobic conditions (Medinets et al., 2015). This process is one of the major contributors to nitrous oxide $\left(\mathrm{N}_{2} \mathrm{O}\right)$ and nitric oxide emissions (NO; Ussiri and Lal, 2013), which have 
severe environmental consequences (Pilegaard, 2013; IPCC, 2014), and are released due to the oxidation of intermediates of the nitrification process, i.e. hydroxylamine $\left(\mathrm{NH}_{2} \mathrm{OH}\right)$ and nitrite $\left(\mathrm{NO}_{2}{ }^{-}\right.$; Ruser and Schulz, 2015). Therefore, the inhibition of the first step of nitrification (oxidation of $\mathrm{NH}_{4}{ }^{+}$to $\mathrm{NH}_{2} \mathrm{OH}$ ) causes a direct reduction of $\mathrm{N}$ oxides $\left(\mathrm{N}_{2} \mathrm{O}+\mathrm{NO}_{\mathrm{x}}\right)$ emissions (Akiyama et al., 2010). In addition, the limited availability of the final product of nitrification, prevents losses of $\mathrm{NO}_{3}{ }^{-}$via leaching to groundwater (Quemada et al., 2013) and $\mathrm{N}$ oxides emissions from denitrification (the heterotrophic reduction of $\mathrm{NO}_{3}{ }^{-}$to $\mathrm{N}_{2}$ ), which has been described as the main $\mathrm{N}_{2} \mathrm{O}$ loss pathway (Skiba and Smith, 2000) and also as a source of NO (Loick et al., 2016). The use of NIs in intensive agriculture, therefore, represents a potential management option to reduce the environmental and health costs associated with these water and atmospheric pollutants (Qiao et al., 2015), providing opportunity for increased benefits through enhancement of $\mathrm{N}$ use efficiency and crop yields (Abalos et al., 2014; Yang et al., 2016).

Many synthetic (Akiyama et al., 2010) and naturally occurring organic compounds (Subbarao et al., 2015) can act as NIs, with dicyandiamide (DCD) and 3,4dimethylpyrazole phosphate (DMPP) representing two of the most commonly researched and used NIs in Europe (Gilsanz et al., 2016). Both NIs deactivate the enzyme responsible for the first step of nitrification, i.e. the oxidation of $\mathrm{NH}_{4}{ }^{+}$to $\mathrm{NH}_{2} \mathrm{OH}$. The main proposed mechanisms of inhibition are: i) direct binding and interaction with ammonium monooxygenase (i.e. indiscriminate binding in the case of DMPP and blocking the electron transport in the cytochromes in the case of DCD, Benckiser et al., 2013); and ii) the removal of copper $(\mathrm{Cu})$ as the co-factor of ammonium monooxygenase, thus behaving as metal chelators (Ruser and Schulz, 2015). With regards to their chemical behaviour, DCD is less volatile than DMPP 
74 (Giltrap et al., 2010), while the water solubility of DMPP $\left(125 \mathrm{~g} \mathrm{l}^{-1}\right)$ is higher than that 75 of DCD (73.2 $\mathrm{g} \mathrm{l}^{-1}$; Marsden et al., 2016). These authors also observed that the distribution of both NIs within soil columns after a rainfall simulation was similar, except for the top $1 \mathrm{~cm}$ (where higher retention of DCD was obtained). DCD has been the main inhibitor employed in several countries such as New Zealand, mainly due to its low cost, although this inhibitor has been voluntarily withdrawn from New Zealand due to the traces of DCD that were found in infant milk exported to China (Pal et al., 2016). On the other hand, DMPP can be added at rates about 10 times less than DCD (Zerulla et al., 2001; Benckiser et al., 2013), with similar, or even higher, reported efficacies (Weiske et al., 2001).

With regards to the inhibition efficiency of DCD and DMPP, published metaanalyses have reported statistically similar average performances of both NIs in mitigating $\mathrm{N}_{2} \mathrm{O}$ emissions (Gilsanz et al., 2016) and enhancing $\mathrm{N}$ use efficiency or crop yields (Abalos et al., 2014). Conversely, several studies have reported that the efficiency of DMPP surpassed that of DCD in decreasing soil $\mathrm{NO}_{3}{ }^{-}$concentrations and/or $\mathrm{N}_{2} \mathrm{O}$ emissions, or increasing crop productivities (Pereira et al., 2010; Liu et al., 2013; Kou et al., 2015). In addition to inhibition efficacy, the behaviour of these products in soil is linked to other soil processes (e.g. mineralization, microbial uptake, water extractability) and hence, to soil properties (Zhang et al., 2004; Barth et al., 2008; McGeough et al., 2016). To date, few studies have evaluated these processes (Marsden et al., 2016), and especially in calcareous alkaline soils. Therefore, it is important to understand the key variables affecting the efficacy and fate of NIs, to underpin advice about which product is the most effective under contrasting environmental and edaphic conditions. 
NIs. For example, the water solubility and leaching potential has been shown to be higher for DCD than DMPP (Weiske et al., 2001; Kim et al., 2012), thus resulting in spatial dislocation of soil $\mathrm{NH}_{4}{ }^{+}$and the inhibitor, possibly affecting the duration of the inhibiting effect. However, a recent study by Marsden et al. (2016) employing ${ }^{14} \mathrm{C}$ labelled NIs, showed that the mobility of both inhibitors were similar. Another possible factor affecting efficacy is the microbial mineralization of NIs. Some studies have found that DCD degrades faster than DMPP in soil, using direct NI measurements by chromatography-based methods (Weiske et al., 2001) or ${ }^{14} \mathrm{C}$ labelling of NIs and subsequent measurement of rates of ${ }^{14} \mathrm{CO}_{2}$ emission after application to soil (Marsden et concentration of the NI in soil solution, and effectiveness on nitrifying microorganisms microbial assimilation of DCD is also expected, due to the lower degradability and bioavailability of the heterocyclic DMPP compound (Chaves et al., 2006).

In addition, soil temperature has been shown to be a key factor affecting the inhibition effect (Mahmood et al., 2011; Menéndez et al., 2012; McGeough et al., 2016), due to the influence on microbial activity, and hence mineralization and nitrification kinetics. The complex interactions between inhibitor type, soil properties and temperature, however, remains poorly understood. Only a few experiments have reported the simultaneous mineralization of NIs and the effects of the NIs on N cycling, with these often being limited to either measuring the effects of NIs on N cycling without considering the disappearance of the NI itself, or where both have been 
measured, this has often been for only short periods of time, e.g. hours to days (e.g. Marsden et al., 2015; Marsden et al., 2016).

In this context, a laboratory experiment was conducted to compare the amount of

${ }^{14} \mathrm{C}$-labelled DCD and DMPP which is sorbed, mineralized and recovered in the soil extractable pool, in two contrasting soils at three different temperatures. The influence of these three factors on the evolution of soil $\mathrm{NH}_{4}{ }^{+}$and $\mathrm{NO}_{3}{ }^{-}$contents were also investigated under laboratory conditions, in the absence of plants. We hypothesized that, (1) greater mineralization would occur for DCD (in comparison to DMPP) and at higher temperatures, thus decreasing the inhibition efficacy, and (2) higher sorption and microbial assimilation would be observed for DCD and in the soil with a higher organic matter content and microbial biomass (Marsden et al., 2016; McGeough et al., 2016), affecting the proportion of NIs mineralized and extracted.

\section{Materials and Methods}

\subsection{Soil properties}

Two contrasting soils (from Spain and from UK) were used in this study (Table 1). We aimed to compare two soils from different climatic areas and agricultural land use, which mainly differed in $\mathrm{pH}$ and organic $\mathrm{C}$ content, factors that are known to greatly influence microbial activity. The soil from Spain ('ES soil') was an arable soil collected from the "El Encín" field station $\left(40^{\circ} 32^{\prime} \mathrm{N}, 3^{\circ} 17^{\prime} \mathrm{W}\right)$ and was a calcareous sandy clay loam Calcic Haploxerept (Soil Survey Staff, 1992) with vermiculite as a dominant clay mineral. The soil from the UK ('UK soil') was collected from a permanent grassland at the Henfaes Agricultural Research Station, Abergwyngregyn, North Wales $\left(53^{\circ} 14^{\prime} \mathrm{N}, 4^{\circ} 01^{\prime} \mathrm{W}\right)$, and was a sandy clay loam textured Typic Eutrudepts (Soil Survey Staff, 1992). At each site, independent replicate soil samples $(n=3 ; 0-10$ $\mathrm{cm}$ ) were collected, sieved to pass $2 \mathrm{~mm}$, and stored at $4{ }^{\circ} \mathrm{C}$ in gas-permeable polythene 
bags until the start of the experiment. Soil moisture content was determined by oven drying $\left(105^{\circ} \mathrm{C}, 24 \mathrm{~h}\right)$ and soil organic matter content by loss-on-ignition $\left(450{ }^{\circ} \mathrm{C}, 16 \mathrm{~h}\right.$; Ball, 1964). Soil $\mathrm{pH}$ was measured using standard electrodes in 1:2.5 (w/v) soil-todistilled water suspensions. Microbial biomass $\mathrm{C}$ and $\mathrm{N}$ were determined by $\mathrm{CHCl}_{3}$ fumigation-extraction according to Voroney et al. (2008) using $\mathrm{K}_{\mathrm{EC}}$ and $\mathrm{K}_{\mathrm{EN}}$ correction factors of 0.35 and 0.50 , respectively. Initial $\mathrm{NO}_{3}{ }^{-}$and $\mathrm{NH}_{4}{ }^{+}$contents in $1: 5(\mathrm{w} / \mathrm{v})$ soilto- $0.5 \mathrm{M} \mathrm{K}_{2} \mathrm{SO}_{4}$ extracts were determined using the colorimetric method of Miranda et al. (2001) and Mulvaney (1996), respectively. Total C and $\mathrm{N}$ in soils were determined by elemental analysis with a LECO TruMac $\mathrm{CN}$ analyzer ${ }^{\circledR}$. Total $\mathrm{Cu}$ content, which could affect the efficacy of NIs (Ruser and Schulz, 2015; McGeough et al., 2016) was determined by atomic absorption spectrophotometry (AAnalyst 700, PerkinElmer 2000), after treating air-dried soil samples with $\mathrm{HNO}_{3}$ and $\mathrm{HF}$, followed by digestion in Teflon bombs in a microwave oven.

\subsection{DMPP and DCD mineralization within soils}

To determine the mineralization rates of $5-{ }^{14} \mathrm{C}-\mathrm{DMPP}$ and $[\mathrm{U}]{ }^{14} \mathrm{C}-\mathrm{DCD}$ (American Radiolabelled Chemicals, St Louis, MO, USA) in the two soils (ES and UK) at contrasting soil temperatures $\left(10,20\right.$ and $\left.30^{\circ} \mathrm{C}\right)$, a replicated $(n=3)$ factorial ${ }^{14} \mathrm{C}$ labelling experiment was employed. Briefly, $5 \mathrm{~g}$ of field-moist soil was weighed into 50 $\mathrm{cm}^{3}$ polypropylene tubes. $\mathrm{NH}_{4} \mathrm{Cl}$ was applied to each treatment at a rate of $100 \mathrm{~kg} \mathrm{~N}^{-}$ ${ }^{1}$ (i.e. $0.5 \mathrm{ml}, 3 \mathrm{~g} \mathrm{NH}_{4} \mathrm{Cl} \mathrm{l}^{-1}$ ), together with ${ }^{14} \mathrm{C}$-DMPP (at a commercial rate of $1 \mathrm{~kg} \mathrm{ha}^{-1}$, i.e. $0.5 \mathrm{ml} 0.03 \mathrm{~g} \mathrm{l}^{-1}$, ca. $2 \mathrm{kBq} \mathrm{ml}^{-1}$ ) or ${ }^{14} \mathrm{C}$-DCD (at a commercial rate of $10 \mathrm{~kg} \mathrm{ha}^{-1}$, i.e.

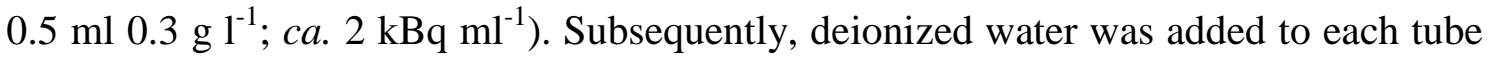
to achieve 50\% water-filled pore space (WFPS) in each soil, maintaining a suitable soil aeration status for nitrification to proceed. WFPS was calculated by dividing the

172 volumetric water content by total soil porosity. Evolved ${ }^{14} \mathrm{CO}_{2}$ was captured in $1 \mathrm{M}$ 
$173 \mathrm{NaOH}$ traps $(1 \mathrm{ml}$; capture efficiency $>95 \%$; Hill et al. 2007), which were changed after $1,3,6,10,14,18,21,28,35$ and 63 days. The ${ }^{14} \mathrm{C}$ activity in the recovered $\mathrm{NaOH}$ solution was determined using a Wallac 1404 Liquid Scintillation Counter (Wallac EG\&G, Milton Keynes, UK) after mixing with HiSafe 3 scintillant (PerkinElmer, Llantrisant, UK). After the last ${ }^{14} \mathrm{CO}_{2}$ measurement, the remaining activity in the soils was quantified by extracting with ice-cold $0.5 \mathrm{M} \mathrm{K}_{2} \mathrm{SO}_{4}(1: 5 \mathrm{w} / \mathrm{v})$. Samples were shaken $\left(150 \mathrm{rev} \mathrm{min}^{-1}\right)$ for $30 \mathrm{~min}$ and subsequently centrifuged (10 $\left.000 \mathrm{~g}, 10 \mathrm{~min}\right)$. The activity in the supernatant was measured as described above.

\subsection{Recovery of ${ }^{14} \mathrm{C}$ in soil extract}

The amount of NI which remained extractable in soil was analysed alongside the mineralization assay described above. In this case, $2 \mathrm{~g}$ of field-moist soil $(n=3)$ was added to $20 \mathrm{ml}$ polypropylene vials. Ammonium chloride and NIs were added at the same rates as in the mineralization experiment, and deionized water was added to reach $50 \%$ WFPS. Labelled ${ }^{14} \mathrm{C}$-NIs were added at $5 \mathrm{kBq} \mathrm{ml}^{-1}(0.2 \mathrm{ml})$. The amount of substrate $\left({ }^{14} \mathrm{C}\right.$-DMPP or ${ }^{14} \mathrm{C}$-DCD) remaining in the soil (combination of the soil solution pool and the exchangeable pool) was measured after 1, 3, 6, 10, 14, 18, 21 and 28 days, by extracting the soil with ice-cold $0.5 \mathrm{M} \mathrm{K}_{2} \mathrm{SO}_{4}$, and analysing the activity in the resulting extracts by liquid scintillation counting, as described in section 2.2 . The mineralization and recovery in soil extract sub experiments involved the same treatments, i.e. two inhibitors (DCD and DMPP), two soils (ES and UK) and three temperatures $\left(10,20\right.$ and $\left.30{ }^{\circ} \mathrm{C}\right)$, and both were used to calculate the ${ }^{14} \mathrm{C}$ mass balance (detailed in section 2.6).

\subsection{NI sorption}



described by Marsden et al. (2015). Briefly, ${ }^{14} \mathrm{C}-\mathrm{DCD}$ or ${ }^{14} \mathrm{C}-\mathrm{DMPP}$ was applied (50 $\mu \mathrm{l}$; ca. $1 \mathrm{kBq})$ to $1 \mathrm{~g}(n=3)$ of air-dried soil, where a total of 8 concentrations of ${ }^{14} \mathrm{C}$-DCD and ${ }^{14} \mathrm{C}$-DMPP were used, ranging from $0.08-10 \mathrm{mg} \mathrm{NI} \mathrm{l}^{-1}$. Subsequently, $5 \mathrm{ml}$ of 0.01 $\mathrm{M} \mathrm{CaCl}_{2}$ was added to the soils and the soil suspensions were shaken $(0.5 \mathrm{~h} ; 150 \mathrm{rev}$ $\left.\min ^{-1}\right)$ on a rotary shaker. An aliquot $(1.5 \mathrm{ml})$ was then centrifuged $(10000 \mathrm{~g} ; 5 \mathrm{~min})$ and the ${ }^{14} \mathrm{C}$ activity in the supernatant determined by liquid scintillation counting as described above. Sorption isotherms were determined for ${ }^{14} \mathrm{C}$-DCD and ${ }^{14} \mathrm{C}$-DMPP in the two contrasting soils and the partition coefficient $\left(K_{\mathrm{d}}\right)$ for the NIs determined via

$$
K_{\mathrm{d}}=C_{\mathrm{ads}} / C_{\mathrm{sol}}
$$

This sorption experiment was measured as a one-off complementary measurement to previous assays (i.e. mineralization and recovery by $\mathrm{K}_{2} \mathrm{SO}_{4}$ extract) for each inhibitor and soil.

\subsection{Soil mineral $N$ content}

Alongside the ${ }^{14} \mathrm{C}$ experiments described above, a further set of samples were established to monitor the effects of the NIs on the dynamics of soil $\mathrm{NH}_{4}{ }^{+}$and $\mathrm{NO}_{3}{ }^{-}$ content over time. $5 \mathrm{~g}$ fresh weight of each soil was weighed into $50 \mathrm{~cm}^{3}$ polypropylene tubes, as for the mineralization experiment. The $\mathrm{NH}_{4} \mathrm{Cl}$ and the NIs (non ${ }^{14} \mathrm{C}$-labelled DCD and DMPP) were applied at the same rates as described in section 2.2 and 2.3. Two additional treatments were included: $\mathrm{NH}_{4} \mathrm{Cl}$ at $100 \mathrm{~kg} \mathrm{~N} \mathrm{ha}^{-1}$ without NIs (no NI) and a control without $\mathrm{NH}_{4} \mathrm{Cl}$ or $\mathrm{NIs}$ addition $(\mathrm{C})$. Deionized water was added to bring the soil in all treatments up to 50\% WFPS, and then the tubes were incubated at 
10, 20 and $30^{\circ} \mathrm{C}$. All the fertilizer-soil-temperature combinations were replicated three times. After $0,1,3,6,10,14,18,21$ and 28 days replicate samples from each treatment $(n=4)$ were destructively harvested and their mineral $\mathrm{N}$ content determined. A 28 day period was chosen based on known period of active inhibition for DMPP and DCD (Benckiser et al., 2013; Chaves et al., 2006). At each sampling date, $\mathrm{NH}_{4}{ }^{+}$and $\mathrm{NO}_{3}{ }^{-}$ were extracted with $25 \mathrm{ml}$ of $0.5 \mathrm{M} \mathrm{K}_{2} \mathrm{SO}_{4}$, and measured using the same procedure described in section 2.1 .

\subsection{Calculations and statistical analysis}

Since it is not possible to determine the ${ }^{14} \mathrm{C}$ recovery in the microbial biomass with any reliability (Glanville et al., 2016), we used a mass balance approach to calculate the amount of ${ }^{14} \mathrm{C}$ present in the microbial biomass. This microbial pool was calculated as the difference between the starting ${ }^{14} \mathrm{C}$ pool (amount of ${ }^{14} \mathrm{C}$ added to the soil at $t=0$ ) and the amount recovered as either ${ }^{14} \mathrm{CO}_{2}$ plus that recovered in the ${ }^{14} \mathrm{C}$ $\mathrm{K}_{2} \mathrm{SO}_{4}$ extractable pool (Glanville et al., 2016; Marsden et al., 2016). The mineralization rates of the inhibitors and the changes in $\mathrm{NH}_{4}{ }^{+}$content with incubation time were modelled with a first- or a zero-order reaction kinetic model, as described in Zhao et al. (2007). Afterwards, the half-life was calculated as $C_{0} / 2 k$ or $\ln (2) / k$ for zero and first-order reactions, respectively, where $C_{0}$ was the initial concentration of substrate and $k$ was the kinetic constant. To determine the significance of the effects of NI type, soil type and temperature on mineralization, ${ }^{14} \mathrm{C}$ recovery in soil extract, and inhibition efficacy, a three-way ANOVA was conducted. The normality (Shapiro-Wilk test) and homogeneity of variance assumptions (Levene's test) were assessed prior to conducting the ANOVA. Data were arcsin or log-transformed before analysis when ANOVA assumptions were not met with the original data. Means were separated by Tukey's honest significance test at $P<0.05$. For non-normally distributed data, the 
246 Kruskal-Wallis test was used on non-transformed data to evaluate differences at $P<$

247 0.05. Linear correlations were carried out to determine relationships between

248 mineralization and recovery in the soil extract with the average $\mathrm{NH}_{4}{ }^{+}$and $\mathrm{NO}_{3}{ }^{-}$contents,

249 considering also the effectiveness on nitrification inhibition (comparison between $\mathrm{NH}_{4}^{+}$

250 and $\mathrm{NO}_{3}{ }^{-}$contents in NIs and $-\mathrm{NI}$ treatments; $n=36$ ). All statistical analyses were

251 carried out with Statgraphics Plus 5.1 (Statpoint Technologies, Inc., The Plains, VA).

\section{3. Results}

\subsection{Mineralization and availability of nitrification inhibitors in soil}

Overall, the NI mineralization patterns were linear and stabilized 63 days after

255

256

257

258

259

260

261

262

263

264

265

266

267

268

269

NIs and $\mathrm{NH}_{4} \mathrm{Cl}$ addition in most treatments (Fig. 1). On average, 6.3 and $11.8 \%$ of ${ }^{14} \mathrm{C}$ DCD and ${ }^{14} \mathrm{C}-\mathrm{DMPP}$, respectively, was mineralized 28 days after $\mathrm{N}$ addition (Table 2). One month later, the cumulative ${ }^{14} \mathrm{CO}_{2}$ released was 10.7 and $15.3 \%$ for DCD and DMPP, respectively. On average for both NIs, the mineralization was highest at $30^{\circ} \mathrm{C}$, and was reduced by $39 \%$ (ranging from $20 \%$ for DMPP to $57 \%$ for DCD) and $49 \%$ (ranging from $26.9 \%$ for DMPP to $70.6 \%$ for DCD) at $20^{\circ} \mathrm{C}$ and $10{ }^{\circ} \mathrm{C}$, respectively $(P$ $<0.05)$. Conversely, the mineralization differences between temperatures were lower for DMPP and only significant when comparing $30{ }^{\circ} \mathrm{C}$ with $20{ }^{\circ} \mathrm{C}$ and $10{ }^{\circ} \mathrm{C}$. The mineralization of DMPP was not affected by soil type, while more DCD was mineralized in the calcareous soil than in the non-calcareous soil $(P<0.05)$. The soil×inhibitor interaction effect on NI mineralization for DCD was particularly marked at $30{ }^{\circ} \mathrm{C}$. DMPP mineralization trends were similar in both soils (Fig. 1c, d) at $30{ }^{\circ} \mathrm{C}$. Conversely, a greater mineralization of DCD was observed in the ES than in the UK soil at this temperature (Fig. 1a, b). The mineralization of NIs in all treatments followed a first-order kinetic relationship (Table 3). Results confirmed that the NI half-life decreased with increasing temperature, and was greater for DCD (635 days) than DMPP 
271 (273 days) across both soil types. Average half-lives for UK and ES soils were 570 and 272338 days, respectively. The sensitivity of mineralization to temperature was evaluated 273 with the $Q_{10}$ parameter (Table S1; Hill et al., 2015). DMPP mineralization showed a significantly lower sensitivity to temperature than DCD mineralization. Regarding the soil effect, the response of the mineralization to temperature was higher in the ES than in the UK soil for DCD (with similar behaviour in both soils for DMPP).

The amount of $\mathrm{K}_{2} \mathrm{SO}_{4}$-extractable DCD and DMPP from soil decreased over time (Fig. 2). The ${ }^{14} \mathrm{C}$ recovered in the $\mathrm{K}_{2} \mathrm{SO}_{4}$ extracts after 63 days ranged from 11 to $66 \%$ of the initial amount of NI applied (Table 2). Recovery of ${ }^{14} \mathrm{C}$ in the extractable pool at both 28 and 63 days was substantially higher for ${ }^{14} \mathrm{C}$-DCD than for ${ }^{14} \mathrm{C}$-DMPP $(P<0.001)$. This pool was also higher in the ES soil than in the UK soil. In contrast, the

${ }^{14} \mathrm{C}$ recovery in the soil extracts was not significantly $(P>0.05)$ affected by temperature at 63 days. A negative correlation between NI mineralization and the amount still present in the soil extractable $\mathrm{K}_{2} \mathrm{SO}_{4}$ pool was found $(P<0.001, n=36, r=-0.63)$. extracted by $\mathrm{K}_{2} \mathrm{SO}_{4}$ ) was significantly higher for DMPP than for DCD (Table 2), and in the UK soil (with lower mineralization and ${ }^{14} \mathrm{C}$ recovery in soil extract) than in the ES soil. As for the $\mathrm{K}_{2} \mathrm{SO}_{4}$ extractable pool, temperature had little influence on the size of the non-recoverable ${ }^{14} \mathrm{C}$ pool (e.g. the mean values ranged from $47 \%$ to $51 \%$ for the different temperatures), and it showed less dependence on time than the other pools (data not shown).

\subsection{Effect of nitrification inhibitors on the net production of mineral $N$}

Ammonium concentrations for each temperature are shown in Fig. 3a, c, e and 
concentrations were particularly clear (and even more long-lasting) at $30{ }^{\circ} \mathrm{C}$, compared with lower temperatures. In the case of DMPP, $\mathrm{NH}_{4}{ }^{+}$concentrations were higher than that in the no NI treatment from the first day after fertilization, while no differences between DCD and no NI were observed during the first 6 days after NIs- $\mathrm{NH}_{4} \mathrm{Cl}$ addition. After 28 days, all fertilized treatments reached the base $\mathrm{NH}_{4}{ }^{+}$levels of the unfertilized control treatment.

Nitrate concentrations increased from 3 days after $\mathrm{NIs}-\mathrm{NH}_{4} \mathrm{Cl}$ addition, reaching maximum values at 17-21 days, remaining nearly constant until the end of the experiment (Fig. 3b, d, f and 4b, d, f). Both inhibitors decreased the measured and average $\mathrm{NO}_{3}{ }^{-}$concentrations compared to the no NI treatments, and even the nonfertilized control treatment $(P<0.05)$. A significant correlation between $\mathrm{NO}_{3}{ }^{-}$ concentrations and NI mineralization was also observed $(P<0.01, n=36, r=0.42)$.

The effectiveness of nitrification inhibition (Table S2) was calculated through the kinetic constant and the half-life of nitrification, as explained in section 2.6. In all cases, nitrification was best described by a first-order kinetic model $(P<0.05)$, except for the DMPP-UK-10 treatment, which was best described by a zero-order kinetic model. The lower the kinetic constant is (or the longer the half-life is), the more effective the inhibitor (the inhibition of nitrification in this case). The nitrification halflife, which ranged from 8 to 75 days, was lowest at $20^{\circ} \mathrm{C}$, compared to $10{ }^{\circ} \mathrm{C}$ and 30 ${ }^{\circ} \mathrm{C}$, for both NIs. As was observed for the recovery of the NIs in the different soil pools $\left({ }^{14} \mathrm{C}-\mathrm{K}_{2} \mathrm{SO}_{4},{ }^{14} \mathrm{CO}_{2},{ }^{14} \mathrm{C}\right.$-microbial biomass), significant interactions were observed regarding the half-life of nitrification. DMPP was more effective (longer half-life of $\mathrm{NH}_{4}{ }^{+}$) than DCD in UK soil, but the opposite (DCD was more effective) was observed in the ES soil (Table S2). Both NIs were more effective in inhibiting $\mathrm{NO}_{3}{ }^{-}$formation in the UK soil compared to the ES soil, although differences between soils were higher for 
DMPP than for DCD. In addition, Figure 5 shows the increase in the half-life of

322

nitrification due to DCD or DMPP, for each soil and temperature, in comparison to the treatments without NIs added. This figure, which represents the inhibitor×soil $\times$ temperature interactions, shows that the lowest efficiency was in the ES soil at $30^{\circ} \mathrm{C}$, for both inhibitors (even there was no effect of DMPP under these conditions, with respect to the addition of no fertilizer or inhibitor). Both soils showed a different trend with regards to temperature: the lowest efficiency occurred at $20{ }^{\circ} \mathrm{C}$ in the UK soil, and at $30{ }^{\circ} \mathrm{C}$ in the ES soil.

\subsection{Sorption of nitrification inhibitors to the solid phase}

Sorption isotherms for DCD and DMPP in the two soils are presented in Figure 6. In the DMPP-ES isotherm one outlier (corresponding to $5 \mathrm{mg}$ DMPP $\mathrm{l}^{-1}, 4.2 \mathrm{mg} \mathrm{l}^{-1}$ in equilibrium) was removed after applying Dixon's Q test. The partition coefficients $\left(K_{\mathrm{d}}\right.$, from 1 to $10 \mathrm{mg} \mathrm{l}^{-1}$ of initial NIs concentration), calculated as the slope of the sorption isotherms corresponding to both soils and inhibitors, were 4.11, 1.43, 0.49 and 0.90 for ES-DCD, UK-DCD, ES-DMPP and UK-DMPP, respectively. This coefficient was higher for DCD than DMPP, regardless of soil type. Conversely, the soilxinhibitor interaction meant that in the case of DCD, $K_{\mathrm{d}}$ was greater in the ES than in the UK soil, while the opposite was observed for DMPP (higher $K_{\mathrm{d}}$ in UK than in ES soil).

\section{Discussion}

\subsection{Nitrification inhibitor mineralization in soil}

Studying the mineralization of NIs in different soils and at different temperatures is an issue of major interest. Under optimal conditions, the NIs should be mineralized at a rate that provides a high level of inhibition, whilst also degrading relatively quickly so as not to disturb wider soil functioning (Ruser and Schulz, 2015), minimise loss to 
watercourses, or enter the food chain (Marsden et al., 2015; Pal et al., 2016).

346 Controversy surrounds this point, however, since a residual effect could contribute to 347 enhanced efficiency of NIs through subsequent cropping campaigns (i.e. legacy effect; 348 Alonso-Ayuso et al., 2016). Contrary to our initial hypothesis, more DMPP than DCD was mineralized at 28 and 63 days after $\mathrm{N}$ addition (Fig. 1, Table 2). In fact, the average half-life of DCD was 2.3 times higher than that of DMPP (Table 3), and was much higher than that reported by the studies of Kelliher et al. (2008; 64 days at $\left.20^{\circ} \mathrm{C}\right)$ or Barneze et al. $(2015 ; 10$ days at $15{ }^{\circ} \mathrm{C}$ ). Our findings are not consistent with previous studies showing that DCD concentrations decline more rapidly in soil than DMPP e.g. in brown earth Fluvisols (Weiske et al., 2001) and loamy sand soils (Zerulla et al., 2001). Our results may be caused by the different experimental conditions, since in the field study of Weiske et al. (2001), the highly soluble DCD could have been leached within the soil profile (Kim et al., 2012), leading to a loss of DCD. However, similar transport of both inhibitors down the soil profile was observed by Marsden et al. (2016). These authors also measured the mineralization $(0-8 \mathrm{~h})$ of both ${ }^{14} \mathrm{C}$-labelled NIs, also finding faster mineralization of DCD than that of DMPP. They argued that the characteristics of the molecule (a heterocyclic compound) cause DMPP to be more resistant to microbial attack (Chaves et al., 2006). Although the authors of these previous studies hypothesized that the microbial community degrade DCD faster than DMPP, this was not measured for a period longer than 24 hours.

The effect of temperature on NI mineralization was largely independent of soil type and inhibitor: with increasing temperatures, a higher percentage of NIs was mineralized. The previous studies of Rajbanshi et al. (1992) or Kelliher et al. (2008) found that the mineralization of DCD increased with temperature, supporting our 
370 findings. The $Q_{10}$ values revealed that the mineralization of DMPP was much less

371 influenced by temperature than that of DCD. Similarly, Menéndez et al. (2012) also

372 found that the persistence of DMPP in soil did not greatly depend on temperature.

373 Kelliher et al. (2008) quantified the relationship between temperature and DCD

374 mineralization, observing that at higher temperatures (e.g. $25^{\circ} \mathrm{C}$ ), a $1{ }^{\circ} \mathrm{C}$ increment

375 caused a disproportional decrease in DCD half-life with respect to the same increase at 376 lower temperatures (e.g. $5^{\circ} \mathrm{C}$ ). Accordingly, in our experiment, the largest differences 377 occurred between $20^{\circ} \mathrm{C}$ and $30^{\circ} \mathrm{C}$, rather than between $10^{\circ} \mathrm{C}$ and $20^{\circ} \mathrm{C}$ (Table S1).

\subsection{Recovery of ${ }^{14}$ C-labelled nitrification inhibitors in soil extracts}

The amount of ${ }^{14} \mathrm{C}$-NIs extracted by $\mathrm{K}_{2} \mathrm{SO}_{4}$ was barely influenced by temperature, particularly in the case of DMPP (Table 2), in agreement with Menéndez et al. (2012). The soil extractable pool was significantly larger for DCD than for DMPP. As $\mathrm{K}_{2} \mathrm{SO}_{4}$ removes the compound from the exchange phase, this result suggests that more DCD may have been left in the soil as less remained unrecoverable (Table 2). This result could also indicate a higher potential of DCD to move within the soil solution and therefore, to be translocated or leached down the soil profile (Kim et al., 2012). Conversely, Marsden et al. (2016) did not find significant differences between the mobility of DCD and that of DMPP, also showing that the solubility of DMPP was higher than that of DCD. With regards to the soil type effect, greater amounts of ${ }^{14} \mathrm{C}$ were recovered in the soil extracts in the calcareous ES soil than in the non-calcareous UK soil, regardless of temperature or type of inhibitor. This suggests there is a greater potential for microbial immobilization in the non-calcareous soil (Marsden et al., 2016), which is consistent with its higher microbial biomass. 

more DCD was sorbed to the soil matrix than DMPP, regardless of soil type. The higher sorption of DCD was consistent with the significantly higher recovery of this inhibitor in the soil $\mathrm{K}_{2} \mathrm{SO}_{4}$ extractable pool. There is not a clear explanation for these results, since DMPP is positively charged, so a higher sorption of this compound would have been expected (as opposed to DCD), particularly at high soil $\mathrm{pH}$ (which causes amphipathic DCD to be negatively charged). Conversely, these results confirmed those of the previous laboratory experiment carried out by Marsden et al. (2016) in contrasting mineral and organic soils. As found by Zhang et al. (2004), higher sorption of DCD was found in the soil with higher $\mathrm{pH}$. These authors suggested that at a more alkaline soil $\mathrm{pH}$, negatively charged DCD becomes sorbed to metal oxides. However, the sorption of DMPP was higher in the UK soil, possibly indicating the key role of negatively charged domains within organic matter in adsorption processes (Marsden et al., 2016).

On average, the amount of NIs in the non-recoverable ${ }^{14} \mathrm{C}$ pool was much lower for DCD (average 32\%) than for DMPP (average 63\%, being the main pool for this inhibitor). This pool could be associated with, i) microbial uptake, as suggested by Marsden et al. (2016); or ii) strong quasi-irreversible binding of NIs into the clays or organic matter matrix, preventing recovery with $\mathrm{K}_{2} \mathrm{SO}_{4}$. The hypothesis of microbial assimilation is consistent with the higher amount of NIs in the non-measured ${ }^{14} \mathrm{C}$ pool which was obtained in the UK soil, with higher $\mathrm{C}$ and $\mathrm{N}$ microbial biomass (Table 1). If 416 the non-measured ${ }^{14} \mathrm{C}$ pool is associated with microbial immobilization, our results 417 show that DMPP was more likely to be taken up by microbes than DCD. In contrast, 418 Marsden et al. (2016) observed a similar microbial uptake for both DCD and DMPP. As 
opposed to DCD, the greatest proportion of DMPP remained non-measured (Table 2), so further research is needed to determine the fate of DMPP which is not mineralized or extracted by $\mathrm{K}_{2} \mathrm{SO}_{4}$. This is particularly important considering the possible negative or positive effects of NIs on non-target microbiota (Kou et al., 2015; Florio et al., 2016; Wang et al., 2017).

\subsection{Linking NIs fate and efficacy}

Our results showed that the effectiveness of DCD and DMPP in delaying nitrification activity differed between both inhibitors, and was highly influenced by soil type and temperature. Contrary to our initial hypothesis, mineralization did not seem to have a major influence on the inhibitors efficacy, as shown by the average half-life of inhibitors (454 days; Table 3), which was much higher than that of the substrate of nitrification $\left(\mathrm{NH}_{4}{ }^{+} ; 36.7\right.$ days; Table S2). Moreover, differences in the mineralization rates at 63 days between each NI-soil-temperature combination did not surpass $15 \%$ (in absolute values).

The efficiency of DCD and DMPP was mainly driven by the interaction with soil type i.e. DMPP was more effective than DCD in the UK soil (Fig. 5 and Table S2), while DCD was more effective than DMPP in the ES soil. The differences between both soils may be explained by the effect of the contrasting physico-chemical properties in both soils. One of these properties was soil $\mathrm{pH}$, which was acidic in the UK soil and alkaline in the ES. Several studies under acidic soil conditions also found that DMPP efficacy was higher than that of DCD (e.g. Weiske et al., 2001; Chaves et al., 2006; Fangueiro et al., 2009; Di and Cameron, 2011). In addition, the specific composition of organic matter and clays, which affects soil CEC, have been shown to affect DCD and DMPP efficacy (Zhang et al., 2004; Wu et al., 2007; Barth et al., 2008; McGeough et al., 2016). The lower recovery rates associated with DMPP and the UK soil may suggest 
444 a greater interaction with the organic fraction (Shi et al., 2016). Otherwise, the contrasting physico-chemical properties (Table 1) as well as climatic conditions (e.g. rainfall amount and distribution), management factors (the UK is a grassland soil and the ES is an arable soil), and plant species identity have all been shown to affect the composition of nitrifying communities (Yao et al., 2011; Carey et al., 2016). For instance, ammonium oxidizing archaea (AOA) dominate nitrification activity in acidic soils (such as UK), while ammonium oxidizing bacteria may dominate in alkaline soils (such as ES). The inhibition of the growth of AOB rather than that of AOA has been proposed as the main mechanism for slowing nitrification activity from DCD and DMPP (Ruser and Schulz, 2015, Shi et al., 2016). The specific microbial composition in each soil could explain the complex soil xinhibitor and soil xtemperature interactions (Fig. 5). Regardless of the type of NI, the acid soil with the lowest CEC and clay content (UK) was associated with significantly higher efficacies of DCD and DMPP (Fig. 5 and Table S2). Even though there are few studies on the effectiveness of DMPP compared to DCD in the UK (Misselbrook et al., 2014), our results suggest the potential of DMPP to achieve higher nitrification inhibition rates than DCD in grassland soils (acid $\mathrm{pH}$ and relatively low CEC) as the UK soil (Fig. 5 and Table S2).

\section{Conclusions} both soils, in comparison to that of DCD, although the kinetics of mineralization of these nitrification inhibitors was not necessarily linked with their overall effectiveness. The effectiveness of both NIs was higher in the more acidic UK soil ( $\mathrm{pH}$ 6.0). The nitrification inhibition efficacy of DMPP was highly dependent on soil type (in comparison to that of DCD), decreasing in the alkaline low-organic $\mathrm{C}$ content soil ( $\mathrm{pH}$ 7.6). Comparing the behaviour of both NIs, higher amounts of ${ }^{14} \mathrm{C}-\mathrm{DCD}$ was sorbed to 
the soil matrix and recovered in the soil extract, while the amount of NIs in the nonmeasured (neither mineralized nor $\mathrm{K}_{2} \mathrm{SO}_{4}$ extracted) pool was much lower for DCD than for DMPP. Temperature was a key factor influencing NIs efficacy (which was at a minimum at $20^{\circ} \mathrm{C}$ and $30^{\circ} \mathrm{C}$ in the acidic UK and calcareous ES soils, respectively) and mineralization (which increased with temperature). The cost-effective use of NIs

474 requires the evaluation of the interactions between the type of NI, soil properties and 475 regional temperature fluctuations. This laboratory experiment is a starting point to analyse the drivers of the efficacy of DMPP and DCD, and contributes to the understanding of the behaviour of both NIs in the soil in the short-term, as well as the possible effects in the medium/long term, which should be confirmed and explored under field conditions.

\section{Acknowledgements}

The authors are grateful to the Spanish Ministry of Economy and Innovation and the Autonomous Community of Madrid for their economic support through Projects, AGL2015-64582-C3-3-R (MINECO/FEDER) and the Agrisost Project (P2013/ABI2717). We also thank the technical support at the Environment Centre Wales (ECW) and particularly to María Jesús García for her help with the soil analyses. This work was done in the frame of the Moncloa Campus of International Excellence (UCM-UPM).

\section{References}

Abalos, D., Jeffery, S., Sanz-Cobena, A., Guardia, G., Vallejo, A., 2014. Meta-analysis of the effect of urease and nitrification inhibitors on crop productivity and nitrogen use efficiency. Agr. Ecosyst. Environ. 189, 136-144. 
491 Akiyama, H., Yan, X., Yagi, K., 2010. Evaluation of effectiveness of 492 enhanced-efficiency fertilizers as mitigation options for $\mathrm{N}_{2} \mathrm{O}$ and $\mathrm{NO}$ emissions from 493 agricultural soils: meta-analysis. Glob. Change Biol. 16, 1837-1846.

494 Alonso-Ayuso, M., Gabriel, J.L., Quemada, M., 2016. Nitrogen use efficiency and 495 residual effect of fertilizers with nitrification inhibitors. Eur. J. Agron. 80, 1-8.

Ball, D.F., 1964. Loss-on-ignition as an estimate of organic matter and organic carbon 497 in non-calcareous soils. Eur. J. Soil Sci. 15, 84-92.

Barneze, A.S., Minet, E.P., Cerri, C.C., Misselbrook, T., 2015. The effect of 499 nitrification inhibitors on nitrous oxide emissions from cattle urine depositions to grassland under summer conditions in the UK. Chemosphere 119, 122-129.

Barth, G., Von Tucher, S., Schmidhalter, U., 2008. Effectiveness of 3,4502 dimethylpyrazole phosphate as nitrification inhibitor in soil as influenced by inhibitor 503 concentration, application form, and soil matric potential. Pedosphere 18, 378-385.

504 Benckiser, G., Christ, E., Herbert, T., Weiske, A., Blome, J., Hardt, M., 2013. The 505 nitrification inhibitor 3, 4-dimethylpyrazole-phosphat (DMPP)-quantification and 506 effects on soil metabolism. Plant Soil 371(1-2), 257-266.

507 Carey, C.J., Dove, N.C., Beman, J.M., Hart, S.C., Aronson, E.L., 2016. Meta-analysis 508 reveals ammonia-oxidizing bacteria respond more strongly to nitrogen addition than 509 ammonia-oxidizing archaea. Soil Biol. Biochem. 99, 158-166.

510 Chaves, B., Opoku, A., De Neve, S., Boeckx, P., Van Cleemput, O., Hofman, G., 2006.

511 Influence of DCD and DMPP on soil N dynamics after incorporation of vegetable crop 512 residues. Biol. Fert. Soils 43(1), 62-68. 
513 Di, H.J., Cameron, K.C., 2011. Inhibition of ammonium oxidation by a liquid

514 formulation of 3, 4-Dimethylpyrazole phosphate (DMPP) compared with a 515 dicyandiamide (DCD) solution in six New Zealand grazed grassland soils. J. Soils 516 Sediments 11(6), 1032.

517 Fangueiro, D., Fernandes, A., Coutinho, J., Moreira, N., Trindade, H., 2009. Influence 518 of two nitrification inhibitors (DCD and DMPP) on annual ryegrass yield and soil 519 mineral N dynamics after incorporation with cattle slurry. Comm. Soil Sci. Plant Anal. $520 \quad 40(21-22), 3387-3398$.

521 Florio, A., Maienza, A., Dell'Abate, M.T., Stazi, S.R., Benedetti, A., 2016. Changes in 522 the activity and abundance of the soil microbial community in response to the 523 nitrification inhibitor 3, 4-dimethylpyrazole phosphate (DMPP). J. Soil Sediments 524 16(12), 2687-2697.

525 Gilsanz, C., Báez, D., Misselbrook, T.H., Dhanoa, M.S., Cárdenas, L.M., 2016. 526 Development of emission factors and efficiency of two nitrification inhibitors, DCD and 527 DMPP. Agr. Ecosyst. Environ. 216, 1-8.

528 Giltrap, D.L., Singh, J., Saggar, S., Zaman, M., 2010. A preliminary study to model the 529 effects of a nitrification inhibitor on nitrous oxide emissions from urine-amended 530 pasture. Agr. Ecosyst. Environ. 136(3), 310-317.

531 Glanville, H.C., Hill, P.W., Schnepf, A., Oburger, E., Jones, D.L., 2016. Combined use 532 of empirical data and mathematical modelling to better estimate the microbial turnover 533 of isotopically labelled carbon substrates in soil. Soil Biol. Biochem. 94, 154-168. 
534 Hill, P.W., Garnett, M.H., Farrar, J., Jones D.L., 2015. Living roots magnify the 535 response of soil organic carbon decomposition to temperature in temperate grassland. 536 Glob. Change Biol. 21, 1368-1375.

Hill, P., Kuzyakov, Y., Jones, D., Farrar, J., 2007. Response of root respiration and root exudation to alterations in root C supply and demand in wheat. Plant Soil 291(1-2), 131141.

540

IPCC, 2014. Climate Change 2014: Synthesis Report. Contribution of Working Groups

I, II and III to the Fifth Assessment Report of the Intergovernmental Panel on Climate Switzerland, $151 \mathrm{pp}$. dependence of dicyandiamide (DCD) degradation in soils: a data synthesis. Soil Biol. Biochem. 40(7), 1878-1882.

547 Kim, D.-G., Giltrap, D., Saggar, S., Palmada, T., Berben, P., Drysdale, D., 2012. Fate of 548 the nitrification inhibitor dicyandiamide (DCD) sprayed on a grazed pasture: effect of 549 rate and time of application. Soil Res. 50(4), 337-347.

550 Kou, Y.P., Wei, K., Chen, G.X., Wang, Z.Y., Xu, H., 2015. Effects of 3, 4551 dimethylpyrazole phosphate and dicyandiamide on nitrous oxide emission in a greenhouse vegetable soil. Plant Soil Environ. 61(1), 29-35.

553 Liu, C., Wang, K., Zheng, X., 2013. Effects of nitrification inhibitors (DCD and DMPP) 554 on nitrous oxide emission, crop yield and nitrogen uptake in a wheat-maize cropping system. Biogeosciences 10(4), 2427. 
556 Loick, N., Dixon, E.R., Abalos, D., Vallejo, A., Matthews, G.P., McGeough, K.L.,

557 Well, R., Watson, C.J., Laughlin, R.M., Cardenas, L.M., 2016. Denitrification as a 558 source of nitric oxide emissions from incubated soil cores from a UK grassland soil. 559 Soil Biol. Biochem. 95, 1-7.

560 Mahmood, T., Ali, R., Latif, Z., Ishaque, W., 2011. Dicyandiamide increases the 561 fertilizer $\mathrm{N}$ loss from an alkaline calcareous soil treated with ${ }^{15} \mathrm{~N}$-labelled urea under warm climate and under different crops. Biol. Fert. Soils 47(6), 619-631.

Marsden, K.A., Marín-Martínez, A.J., Vallejo, A., Hill, P.W., Jones, D.L., Chadwick, D.R., 2016. The mobility of nitrification inhibitors under simulated ruminant urine deposition and rainfall: a comparison between DCD and DMPP. Biol. Fert. Soils 52(4), 491-503.

Marsden, K.A., Scowen, M., Hill, P.W., Jones, D.L., Chadwick, D.R., 2015. Plant acquisition and metabolism of the synthetic nitrification inhibitor dicyandiamide and naturally-occurring guanidine from agricultural soils. Plant Soil 395(1-2), 201-214.

571 Evidence that the efficacy of the nitrification inhibitor dicyandiamide (DCD) is affected by soil properties in UK soils. Soil Biol. Biochem. 94, 222-232. NO transformation: Associated processes and possible physiological significance on organisms. Soil Biol. Biochem. 80, 92-117.

576 Menéndez, S., Barrena, I., Setien, I., González-Murua, C., Estavillo, J.M., 2012.

577 Efficiency of nitrification inhibitor DMPP to reduce nitrous oxide emissions under 578 different temperature and moisture conditions. Soil Biol. Biochem. 53, 82-89. 
579 Miranda K.M., Epsey, M.G., Wink, D.A., 2001. A rapid, simple, spectrophotometric 580 method for simultaneous detection of nitrate and nitrite. Nitric Oxide 5, 62-71.

581 Misselbrook, T.H., Cardenas, L.M., Camp, V., Thorman, R.E., Williams, J.R., Rollett, 582 A.J., Chambers, B.J., 2014. An assessment of nitrification inhibitors to reduce nitrous 583 oxide emissions from UK agriculture. Environ. Res. Lett. 9(11), 115006.

584 Mulvaney, R.L., 1996. Nitrogen—inorganic forms. In: Sparks, D.L. (Ed.), Methods of 585 soil analysis. Part 3. Soil Science Society of America Inc., Madison, WI, pp. 11235861184.

Pal, P., McMillan, A.M., Saggar, S., 2016. Pathways of dicyandiamide uptake in pasture 588 plants: a laboratory study. Biol. Fert. Soils 52(4), 539-546.

Pereira, J., Fangueiro, D., Chadwick, D.R., Misselbrook, T.H., Coutinho, J., Trindade, H., 2010. Effect of cattle slurry pre-treatment by separation and addition of nitrification 591 inhibitors on gaseous emissions and $\mathrm{N}$ dynamics: a laboratory study. Chemosphere 592 $79(6), 620-627$.

593

Pilegaard, K., 2013. Processes regulating nitric oxide emissions from soils. Philos. Trans. Royal Soc. B. 368(1621), 20130126.

595 Qiao, C., Liu, L., Hu, S., Compton, J.E., Greaver, T.L., Li, Q., 2015. How inhibiting 596 nitrification affects nitrogen cycle and reduces environmental impacts of anthropogenic 597 nitrogen input. Glob. Change Biol. 21, 1249-1257.

Quemada, M., Baranski, M., Nobel-de Lange, M.N.J., Vallejo, A., Cooper, J.M., 2013. Meta-analysis of strategies to control nitrate leaching in irrigated agricultural systems and their effects on crop yield. Agr. Ecosyst. Environ. 174, 1-10. 
601 Rajbanshi, S.S., Benckiser, G., Ottow, J.C.G., 1992. Effects of concentration, 602 incubation temperature, and repeated applications on degradation kinetics of 603 dicyandiamide (DCD) in model experiments with a silt loam soil. Biol. Fert. Soils 604 13(2), 61-64.

605

Ruser, R., Schulz, R., 2015. The effect of nitrification inhibitors on the nitrous oxide

606 $\left(\mathrm{N}_{2} \mathrm{O}\right)$ release from agricultural soils—a review. J. Plant Nutr. Soil Sci. 178(2), 171607 188.

608

Shi, X., Hu, H., He, J., Chen, D., Suter, H.C., 2016. Effects of 3, 4-dimethylpyrazole

609 phosphate (DMPP) on nitrification and the abundance and community composition of 610 soil ammonia oxidizers in three land uses. Biol. Fert. Soils 52(7), 927-939.

611

Skiba, U., Smith, K.A., 2000. The control of nitrous oxide emissions from agricultural and natural soils. Chemosphere Glob. Chang. Sci. 2(3), 379-386.

613

Subbarao, G.V., Yoshihashi, T., Worthington, M., Nakahara, K., Ando, Y., Sahrawat, K.L., Rao, I.M., Lata, J.C., Kishii, M., Braun, H.J., 2015. Suppression of soil nitrification by plants. Plant Sci. 233, 155-164.

616

Ussiri, D., Lal, R., 2013. Soil emission of nitrous oxide and its mitigation, Springer Science \& Business Media, pp. 64-89.

Voroney, R.P., Brookes, P.C., Beyaert, R.P., 2008. Soil microbial biomass C, N, P and S. In: Carter, M.R., Gregorich, E.G. (eds) Soil sampling and methods of analysis, 2nd 620 edn. CRC Press, Boca Raton, FL, pp. 637-651. of the nitrification inhibitor dicyandiamide (DCD) on $\mathrm{N}_{2} \mathrm{O}$ emissions and the abundance 
of nitrifiers and denitrifiers in two contrasting agricultural soils. J. Soil Sediments 17(6), 1635-1643.

Weiske, A., Benckiser, G., Ottow, J.C., 2001. Effect of the new nitrification inhibitor DMPP in comparison to DCD on nitrous oxide $\left(\mathrm{N}_{2} \mathrm{O}\right)$ emissions and methane $\left(\mathrm{CH}_{4}\right)$ oxidation during 3 years of repeated applications in field experiments. Nutr. Cycl. Agroecosys. 60(1), 57-64.

Wu, S.F., Wu, L.H., Shi, Q.W., Wang, Z.Q., Chen, X.Y., Li, Y.S., 2007. Effects of a new nitrification inhibitor 3, 4-dimethylpyrazole phosphate (DMPP) on nitrate and potassium leaching in two soils. J. Environ. Sci. 19(7), 841-847.

Yang, M., Fang, Y., Sun, D., Shi, Y., 2016. Efficiency of two nitrification inhibitors (dicyandiamide and 3, 4-dimethypyrazole phosphate) on soil nitrogen transformations and plant productivity: a meta-analysis. Sci. Rep. 6, 22075.

Yao, H., Gao, Y., Nicol, G.W., Campbell, C.D., Prosser, J.I., Zhang, L., Han, W., Singh, B.K., 2011. Links between ammonia oxidizer community structure, abundance, and nitrification potential in acidic soils. Appl. Environ. Microbiol. 77(13), 4618-4625.

Zerulla, W., Barth, T., Dressel, J., Erhardt, K., Horchler von Locquenghien, K., Pasda, G., Rädle, M., Wissemeier, A., 2001. 3, 4-Dimethylpyrazole phosphate (DMPP)-a new nitrification inhibitor for agriculture and horticulture. Biol. Fert. Soils 34(2), 79-84.

Zhang, H.J., Wu, Z.J., Zhou, Q.X., 2004. Dicyandiamide sorption-desorption behaviour on soils and peat humus. Pedosphere 14 395-399.

Zhao, W., Cai, Z.C., Xu, Z.H., 2007. Does ammonium-based N addition influence nitrification and acidification in humid subtropical soils of China? Plant Soil 297(1-2), 213-221. 


\section{Figure captions}

648 Fig. 1 Mineralization of NIs (DCD or DMPP) expressed as a percentage of the total ${ }^{14} \mathrm{C}$ 649 substrate added to two contrasting soils at the three different temperatures $\left(10,20\right.$ and $\left.30{ }^{\circ} \mathrm{C}\right)$. 650 The panels show DCD mineralization in a) UK soil and b) ES soil, and for DMPP in the c) UK 651 soil and d) ES soil. Vertical bars indicate standard errors of the mean $(n=3)$.

652 Fig. 2 Recovery of ${ }^{14} \mathrm{C}$-labelled NIs (DCD or DMPP) with $0.5 \mathrm{M} \mathrm{K}_{2} \mathrm{SO}_{4}$ expressed as a 653 percentage of the total ${ }^{14} \mathrm{C}$-substrate added to two contrasting soils at the three different 654 temperatures $\left(10,20\right.$ and $\left.30^{\circ} \mathrm{C}\right)$. The panels show DCD mineralization in a) UK soil and b) ES 655 soil, and for DMPP in the c) UK soil and d) ES soil. Vertical bars indicate standard errors of the 656 mean $(n=3)$.

658 Fig. 3 Soil $\mathrm{NH}_{4}{ }^{+}$(left) and $\mathrm{NO}_{3}{ }^{-}$(right) contents at $10{ }^{\circ} \mathrm{C}(\mathbf{a}, \mathbf{b}), 20^{\circ} \mathrm{C}(\mathbf{c}, \mathbf{d})$ and $30{ }^{\circ} \mathrm{C}(\mathbf{e}, \mathbf{f})$ for 659 DCD, DMPP, $\mathrm{NH}_{4} \mathrm{Cl}$ without nitrification inhibitors (no NI) and control (C) in the ES soil (see 660 Table 1). Vertical bars indicate standard errors of the mean $(n=3)$.

661 Fig. 4 Soil $\mathrm{NH}_{4}{ }^{+}$(left) and $\mathrm{NO}_{3}{ }^{-}$(right) contents at $10{ }^{\circ} \mathrm{C}(\mathbf{a}, \mathbf{b}), 20^{\circ} \mathrm{C}(\mathbf{c}, \mathbf{d})$ and $30{ }^{\circ} \mathrm{C}(\mathbf{e}, \mathbf{f})$ for 662 DCD, DMPP, $\mathrm{NH}_{4} \mathrm{Cl}$ without nitrification inhibitors (no NI) and control (C) in the UK soil (see 663 Table 1). Vertical bars indicate standard errors of the mean $(n=3)$.

664 Fig. 5 Increase in half-lives (days) of nitrification for the inhibitors (DCD and DMPP) in the 665 two soils (ES and UK, see Table 1) and for the three temperatures tested $\left(10,20\right.$ and $30{ }^{\circ} \mathrm{C}$ ) with 666 respect to no application of nitrification inhibitors. Vertical bars indicate standard errors of the 667 mean $(n=3)$.

668 Fig. 6 Sorption isotherms for ${ }^{14} \mathrm{C}-\mathrm{DCD}$ in the a) UK soil b) ES soil, and for ${ }^{14} \mathrm{C}$-DMPP in the c) 669 UK soil and d) ES soil. Bi-directional error bars represent the standard errors of the mean for 670 sorption and equilibrium solution concentrations $(n=3)$. 
Table 1 Properties of soils $(0-10 \mathrm{~cm})$ used in the experiment.

\begin{tabular}{|c|c|c|}
\hline \multirow{2}{*}{ Parameter } & \multicolumn{2}{|c|}{ Soil } \\
\hline & ES (Sandy clay loam) & UK (Loam) \\
\hline Sand $(\%)$ & 55 & 49 \\
\hline Silt $(\%)$ & 17 & 31 \\
\hline Clay $(\%)$ & 28 & 20 \\
\hline Bulk density $\left(\mathrm{g} \mathrm{cm}^{-3}\right)$ & 1.4 & 1.1 \\
\hline Cation exchange capacity (meq $100 \mathrm{~g}^{-1}$ ) & 25.7 & 14 \\
\hline $\mathrm{pH}$ & 7.6 & 6.0 \\
\hline $\mathrm{CaCO}_{3}\left(\mathrm{~g} \mathrm{~kg}^{-1}\right)$ & 13.2 & $<0.1$ \\
\hline Total organic $\mathrm{C}(\%)$ & 0.8 & 3.1 \\
\hline Extractable $\mathrm{NO}_{3}^{-}\left(\mathrm{mg} \mathrm{N} \mathrm{kg}^{-1}\right)$ & $1.33 \pm 0.1 \mathrm{~b}$ & $0.88 \pm 0.1 \mathrm{a}$ \\
\hline Extractable $\mathrm{NH}_{4}^{+}\left(\mathrm{mg} \mathrm{N} \mathrm{kg}^{-1}\right)$ & $0.02 \pm 0.0 \mathrm{a}$ & $0.24 \pm 0.0 \mathrm{~b}$ \\
\hline Total N (\%) & $0.13 \pm 0.0 \mathrm{a}$ & $0.24 \pm 0.0 \mathrm{~b}$ \\
\hline Total C (\%) & $1.46 \pm 0.0 \mathrm{a}$ & $2.64 \pm 0.1 \mathrm{~b}$ \\
\hline $\mathrm{C}: \mathrm{N}$ ratio & $11.45 \pm 0.1$ & $10.93 \pm 0.3$ \\
\hline $\mathrm{Cu}\left(\mathrm{mg} \mathrm{kg}^{-1}\right)$ & $15.3 \pm 0.1 \mathrm{a}$ & $23.3 \pm 0.3 \mathrm{~b}$ \\
\hline Microbial C $\left(\mathrm{g} \mathrm{kg}^{-1}\right)$ & $0.22 \pm 0.03 \mathrm{a}$ & $0.28 \pm 0.03 \mathrm{~b}$ \\
\hline Microbial N $\left(\mathrm{mg} \mathrm{kg}^{-1}\right)$ & $3.64 \pm 0.55 \mathrm{a}$ & $22.08 \pm 1.08 \mathrm{~b}$ \\
\hline
\end{tabular}

Different letters within rows indicate significant differences by applying the Tukey's honest significance test at $P<0.05$. Values represent means \pm standard error of the mean (when included). 
Table 2 Proportion of ${ }^{14} \mathrm{C}$-labelled nitrification inhibitors mineralized, recoverable by $0.5 \mathrm{M}$ $\mathrm{K}_{2} \mathrm{SO}_{4}$ or unrecoverable for ES and UK soils (see Table 1) incubated at different temperatures $\left(10,20\right.$ and $\left.30^{\circ} \mathrm{C}\right)$ for either 1 or 2 months.

\begin{tabular}{|c|c|c|c|c|c|c|}
\hline \multirow{2}{*}{ Factor } & \multicolumn{2}{|c|}{ Microbial mineralization (\%) } & \multicolumn{2}{|c|}{$\begin{array}{c}\text { Recovery by } \mathrm{K}_{2} \mathrm{SO}_{4} \text { extract } \\
(\%)\end{array}$} & \multicolumn{2}{|c|}{$\begin{array}{c}\text { Non-recoverable } \\
(\%)\end{array}$} \\
\hline & 28 days & 63 days & 28 days & 63 days & 28 days & 63 days \\
\hline \multicolumn{7}{|l|}{ Inhibitor } \\
\hline DCD & $6.3 \mathrm{a}$ & $10.7 \mathrm{a}$ & $67.0 \mathrm{~b}$ & $58.7 \mathrm{~b}$ & $26.6 \mathrm{a}$ & $31.9 \mathrm{a}$ \\
\hline DMPP & $11.8 \mathrm{~b}$ & $15.3 \mathrm{~b}$ & $21.6 \mathrm{a}$ & $17.3 \mathrm{a}$ & $66.6 \mathrm{~b}$ & $67.3 \mathrm{~b}$ \\
\hline S.E. & 0.2 & 0.4 & 0.35 & 1.4 & 0.36 & 1.6 \\
\hline \multicolumn{7}{|l|}{ Soil } \\
\hline UK & $7.7 \mathrm{a}$ & $10.5 \mathrm{a}$ & $39.2 \mathrm{a}$ & $31.4 \mathrm{a}$ & $53.1 \mathrm{~b}$ & $58.1 \mathrm{~b}$ \\
\hline ES & $10.3 \mathrm{~b}$ & $15.5 \mathrm{~b}$ & $49.4 \mathrm{~b}$ & $44.7 \mathrm{~b}$ & $40.2 \mathrm{a}$ & $41.2 \mathrm{a}$ \\
\hline S.E. & 0.2 & 0.4 & 0.35 & 1.4 & 0.43 & 1.6 \\
\hline \multicolumn{7}{|l|}{ Temperature $\left({ }^{\circ} \mathrm{C}\right)$} \\
\hline 10 & $6.0 \mathrm{a}$ & $9.4 \mathrm{a}$ & $46.3 \mathrm{c}$ & 39.4 & $47.7 \mathrm{~b}$ & $51.2 \mathrm{~b}$ \\
\hline 20 & $8.1 \mathrm{~b}$ & $11.3 \mathrm{~b}$ & $44.6 \mathrm{~b}$ & 38.2 & $47.3 \mathrm{~b}$ & $50.5 \mathrm{ab}$ \\
\hline 30 & $12.9 \mathrm{c}$ & $18.4 \mathrm{c}$ & $42.1 \mathrm{a}$ & 36.5 & $45.0 \mathrm{a}$ & $47.2 \mathrm{a}$ \\
\hline S.E. & 0.20 & 0.4 & 0.43 & 1.7 & 0.43 & 1.4 \\
\hline \multicolumn{7}{|l|}{ Inhibitor by Soil } \\
\hline DCD- UK & $3.9 \mathrm{a}$ & $6.2 \mathrm{a}$ & 62.0 & 51.8 & $34.0 \mathrm{~b}$ & 42.0 \\
\hline DCD-ES & $8.6 \mathrm{~b}$ & $15.2 \mathrm{~b}$ & 72.0 & 65.7 & $19.2 \mathrm{a}$ & 21.9 \\
\hline DMPP-UK & $11.5 \mathrm{c}$ & $14.9 \mathrm{c}$ & 16.4 & 11.0 & $72.1 \mathrm{~d}$ & 74.1 \\
\hline DMPP-ES & $11.9 \mathrm{~d}$ & $15.8 \mathrm{c}$ & 26.8 & 23.7 & $61.2 \mathrm{c}$ & 60.5 \\
\hline S.E. & 0.2 & 0.5 & 0.49 & 2.0 & 0.5 & 1.6 \\
\hline \multicolumn{7}{|c|}{ Soil by Temperature } \\
\hline UK-10 & $5.3 \mathrm{a}$ & $7.8 \mathrm{a}$ & $43.7 \mathrm{c}$ & 31.9 & $51.0 \mathrm{~d}$ & 60.3 \\
\hline UK-20 & $7.6 \mathrm{c}$ & $10.8 \mathrm{~b}$ & $40.0 \mathrm{~b}$ & 31.8 & $52.4 \mathrm{e}$ & 57.3 \\
\hline UK- 30 & $10.3 \mathrm{e}$ & $13.0 \mathrm{c}$ & $33.9 \mathrm{a}$ & 30.4 & $55.8 \mathrm{f}$ & 56.6 \\
\hline ES-10 & $6.8 \mathrm{~b}$ & $11.0 \mathrm{~b}$ & $48.9 \mathrm{~d}$ & 47.0 & $44.4 \mathrm{c}$ & 42.0 \\
\hline ES-20 & $8.7 \mathrm{~d}$ & $11.7 \mathrm{c}$ & $49.1 \mathrm{~d}$ & 44.6 & $42.2 \mathrm{~b}$ & 43.7 \\
\hline ES-30 & $15.5 \mathrm{f}$ & $23.9 \mathrm{~d}$ & $50.0 \mathrm{~d}$ & 42.5 & $34.1 \mathrm{a}$ & 37.8 \\
\hline S.E. & 0.3 & 0.6 & 0.6 & 2.5 & 0.62 & 2.0 \\
\hline \multicolumn{7}{|c|}{ Inhibitor by Temperature } \\
\hline DCD-10 & 3.4 & $5.5 \mathrm{a}$ & $71.1 \mathrm{~d}$ & 62.8 & $25.4 \mathrm{a}$ & 31.7 \\
\hline DCD-20 & 5.0 & $8.0 \mathrm{~b}$ & $67.5 \mathrm{c}$ & 57.7 & $27.5 \mathrm{~b}$ & 34.3 \\
\hline DCD-30 & 10.4 & $18.7 \mathrm{e}$ & $62.5 \mathrm{~b}$ & 55.7 & $26.9 \mathrm{~b}$ & 29.8 \\
\hline DMPP-10 & 8.7 & $13.3 \mathrm{c}$ & $21.5 \mathrm{a}$ & 16.1 & $69.9 \mathrm{f}$ & 70.6 \\
\hline DMPP-20 & 11.2 & $14.6 \mathrm{~d}$ & $21.7 \mathrm{a}$ & 18.7 & $67.0 \mathrm{e}$ & 66.7 \\
\hline DMPP-30 & 15.3 & $18.2 \mathrm{e}$ & $21.7 \mathrm{a}$ & 17.2 & $63.0 \mathrm{~d}$ & 64.6 \\
\hline S.E. & 0.3 & 0.6 & 0.6 & 2.5 & 0.62 & 2.0 \\
\hline
\end{tabular}

Different letters within columns indicate significant differences by applying the Tukey's honest significance test at $P<0.05$. Standard Error (S.E.) is given for each effect $(n=3)$. 
Table 3 Half-life of each nitrification inhibitor (DCD and DMPP) in the two soils (ES and UK) at three different temperatures $\left(10,20\right.$ and $\left.30{ }^{\circ} \mathrm{C}\right)$. The $\mathrm{R}^{2}$ coefficient indicates the degree and significance of correlation with a first-order kinetic model (the $\mathrm{P}$ value was $<0.01$ for all treatments). S.E. $=$ Standard Error.

\begin{tabular}{ccc}
\hline Treatment & Half-life (days) & $\mathrm{R}^{2}$ \\
\hline UK 10 DCD & 1222 & 0.87 \\
UK 20 DCD & 786 & 0.95 \\
UK 30 DCD & 520 & 0.93 \\
ES 10 DCD & 654 & 0.96 \\
ES 20 DCD & 444 & 0.93 \\
ES 30 DCD & 186 & 0.98 \\
UK 10 DMPP & 360 & 0.90 \\
UK 20 DMPP & 273 & 0.82 \\
UK 30 DMPP & 260 & 0.68 \\
ES 10 DMPP & 245 & 0.96 \\
ES 20 DMPP & 288 & 0.79 \\
ES 30 DMPP & 211 & 0.75 \\
S.E. & 88 & \\
\hline
\end{tabular}


Figure
Click here to download high resolution image

a)

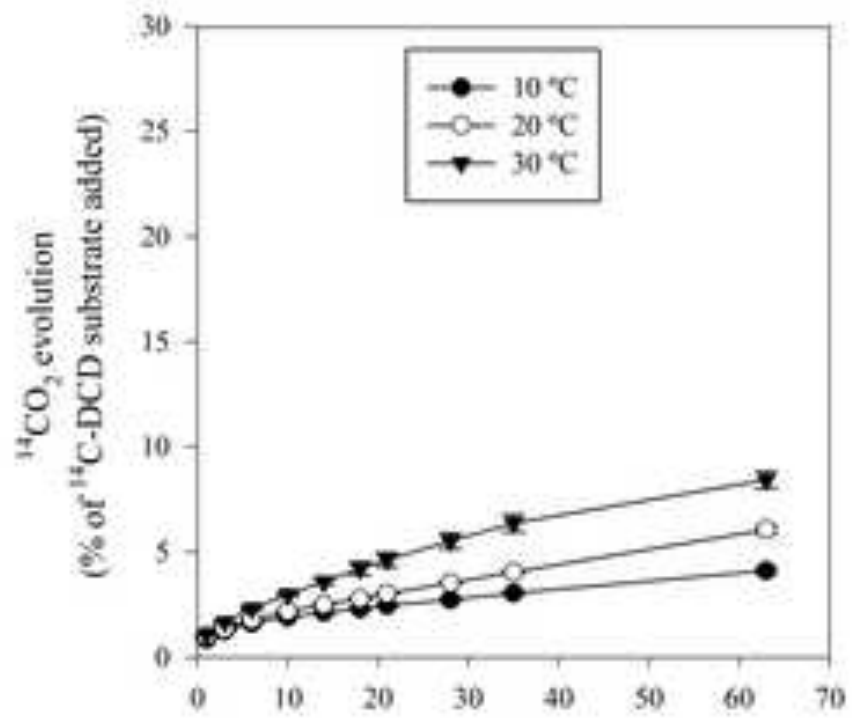

c)

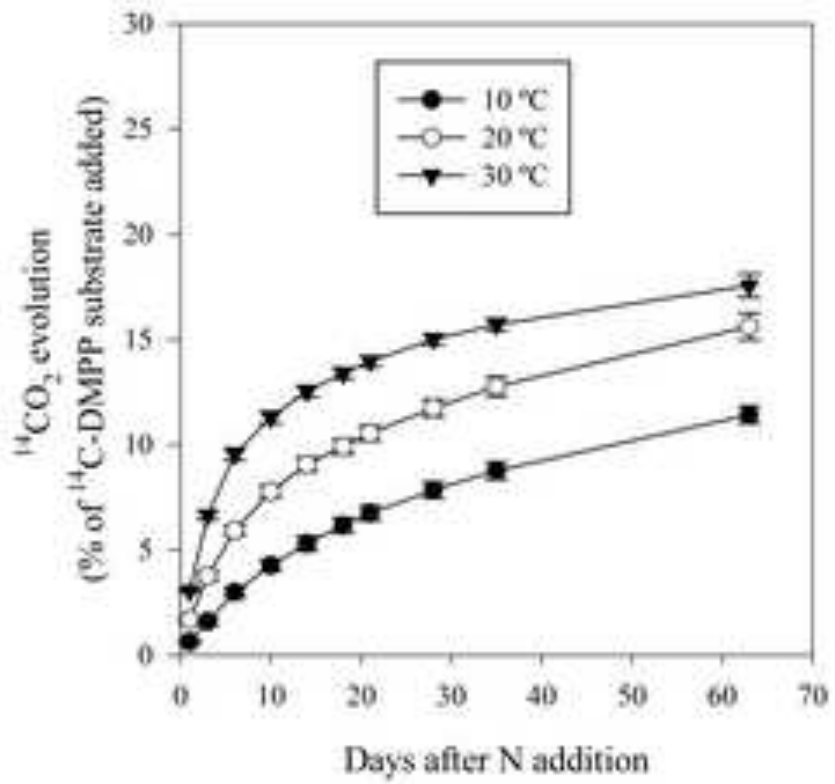

b)

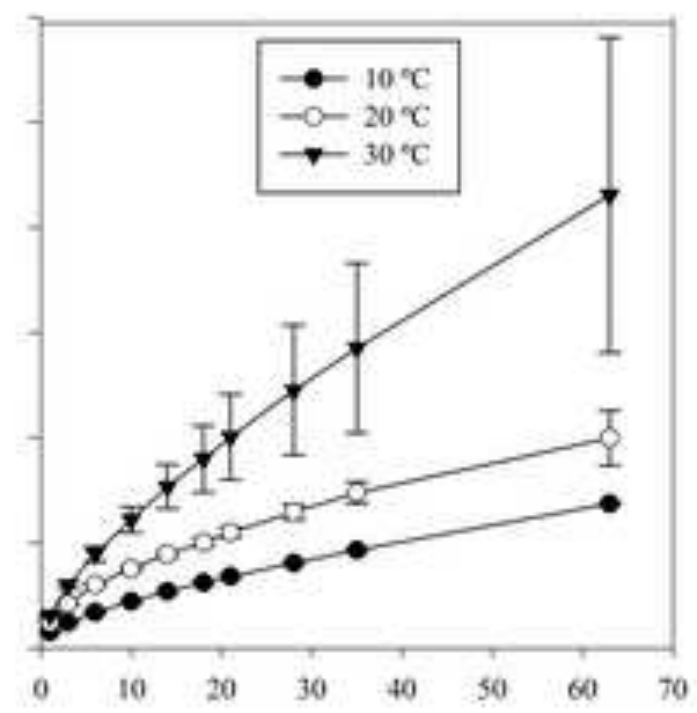

d)

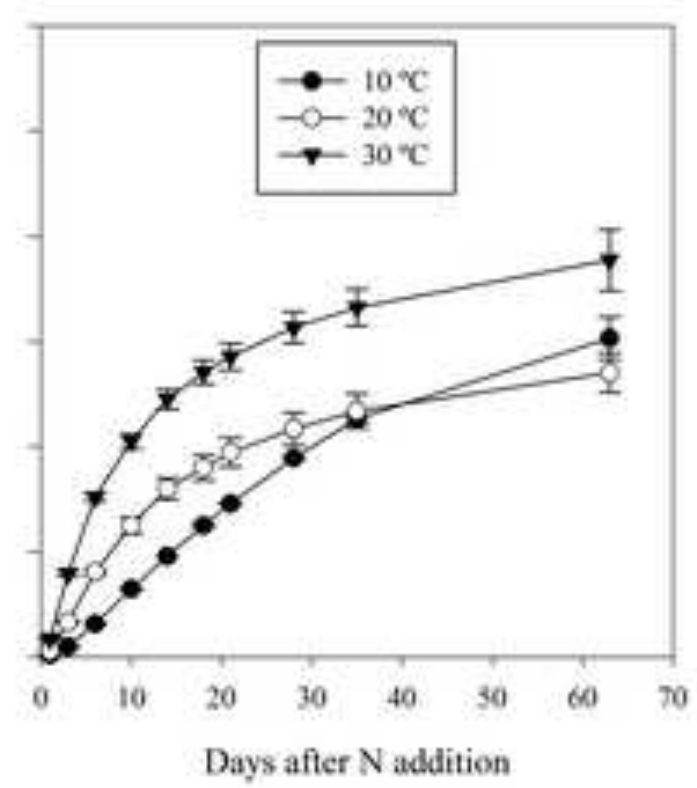




\section{Figure}

Click here to download high resolution image

a)

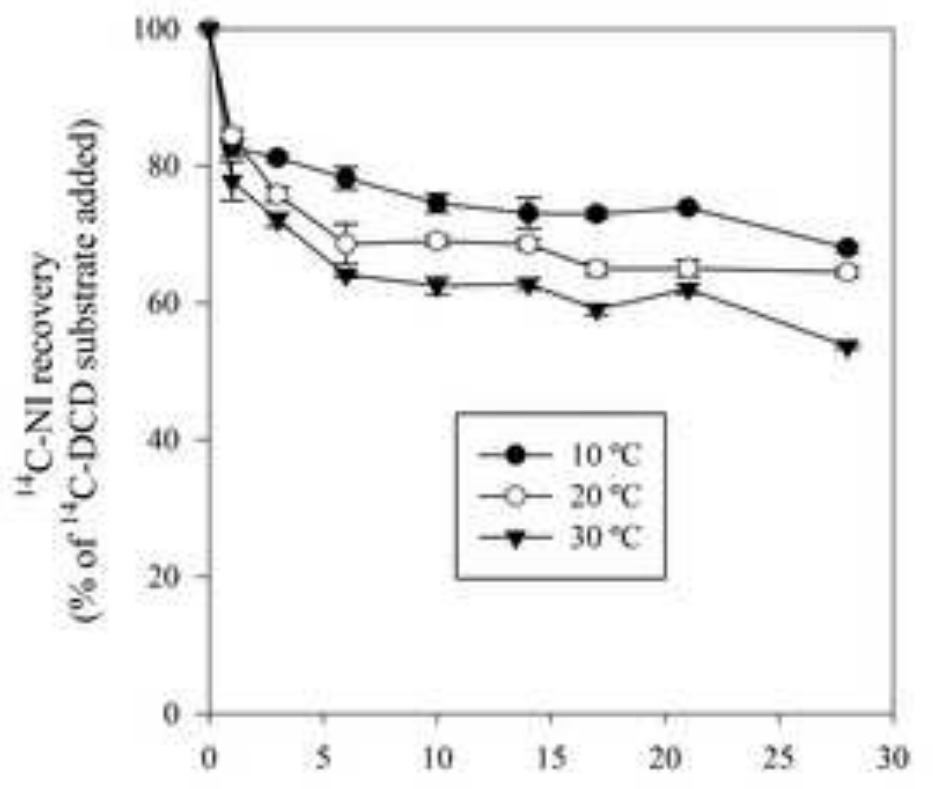

c)

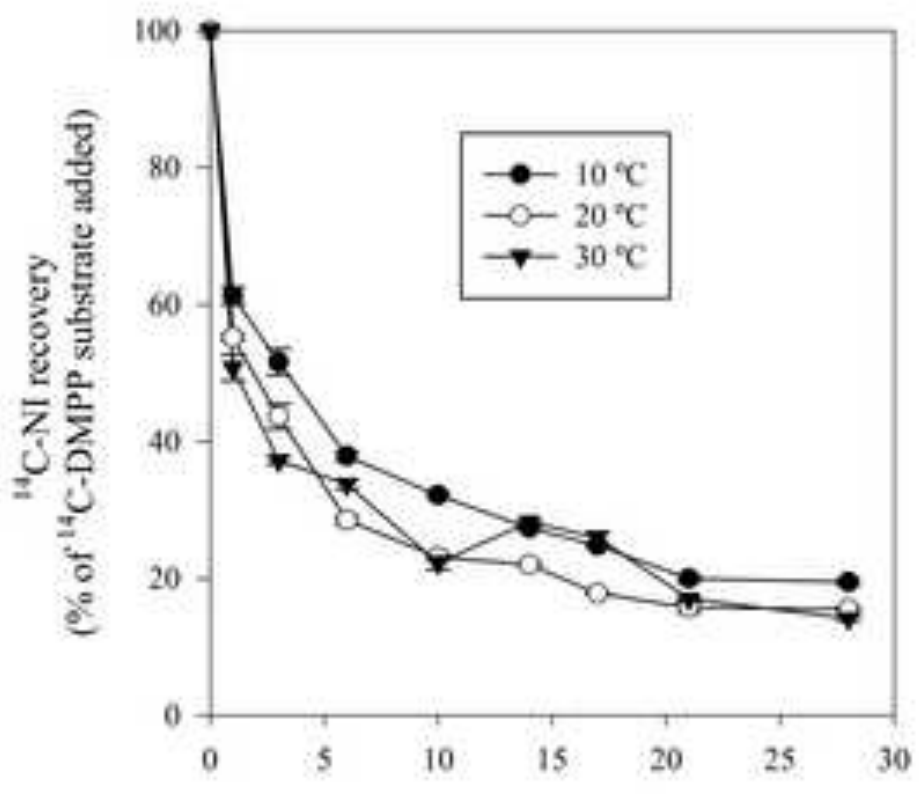

Days affer $\mathrm{N}$ addition b)

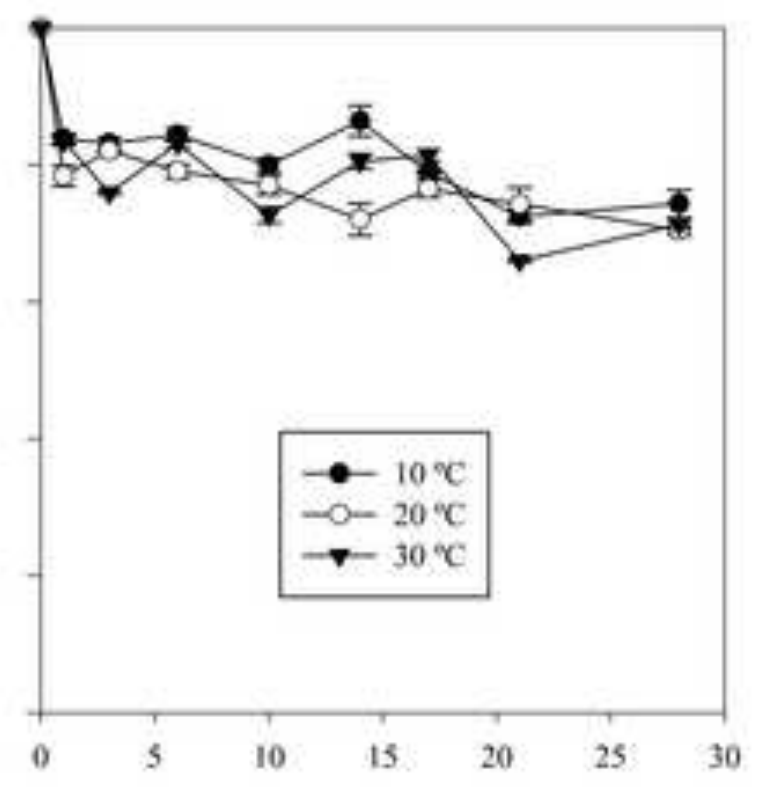

d)

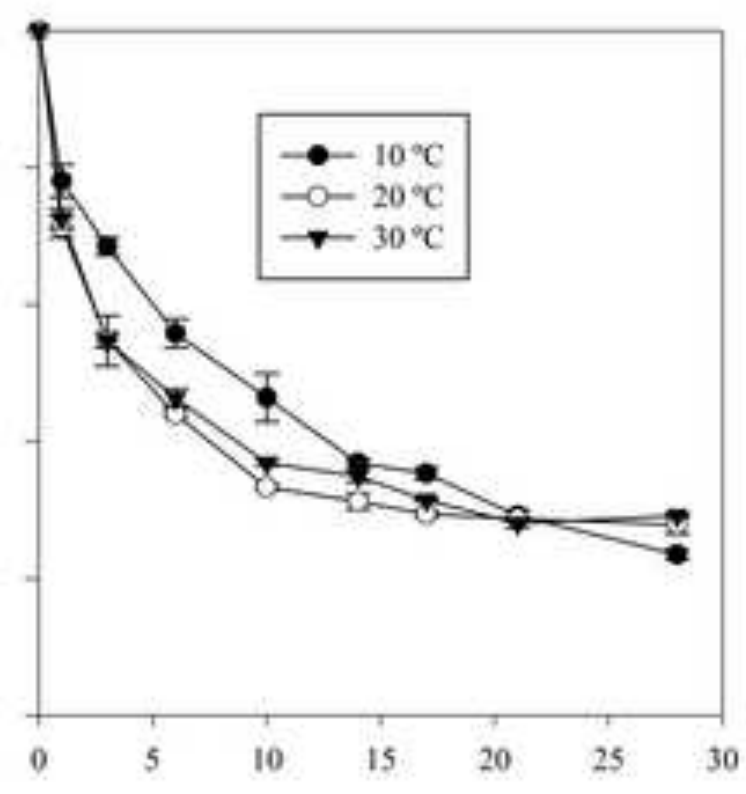

Days after $\mathrm{N}$ addition 
a) $10^{\circ} \mathrm{C}$

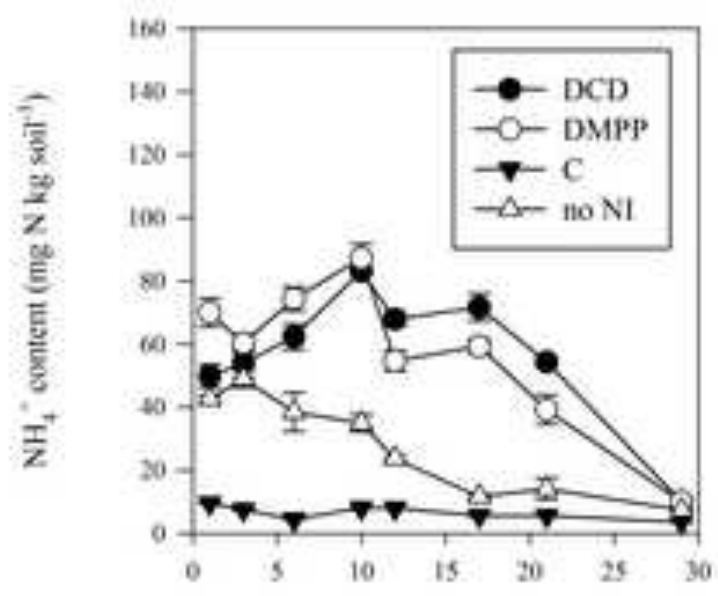

c) $20^{\circ} \mathrm{C}$

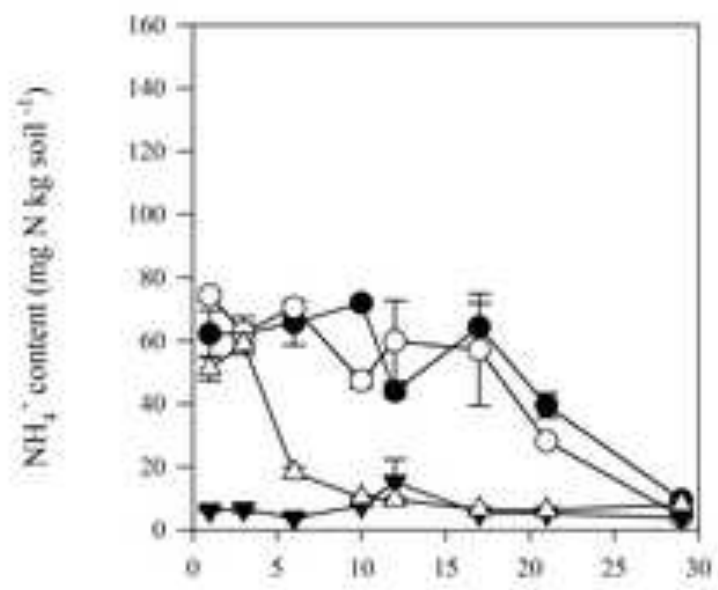

c) $30^{\circ} \mathrm{C}$

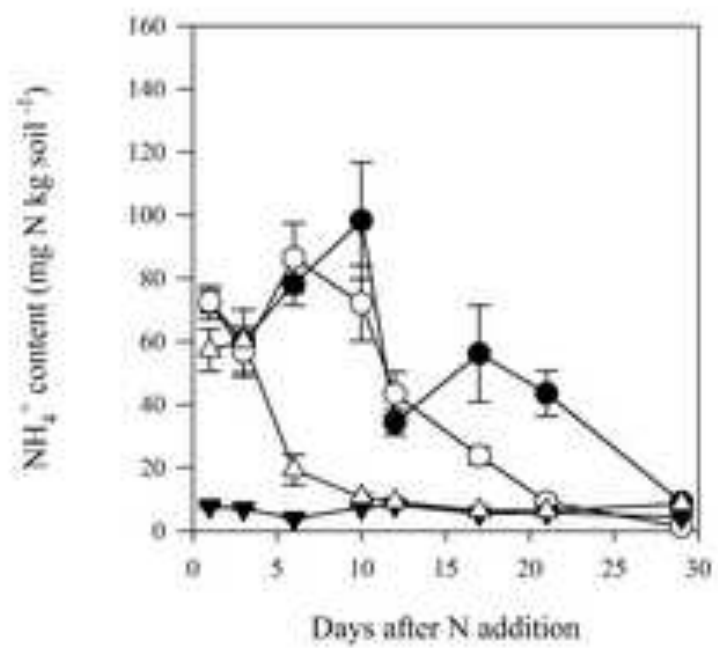

b) $10^{\circ} \mathrm{C}$

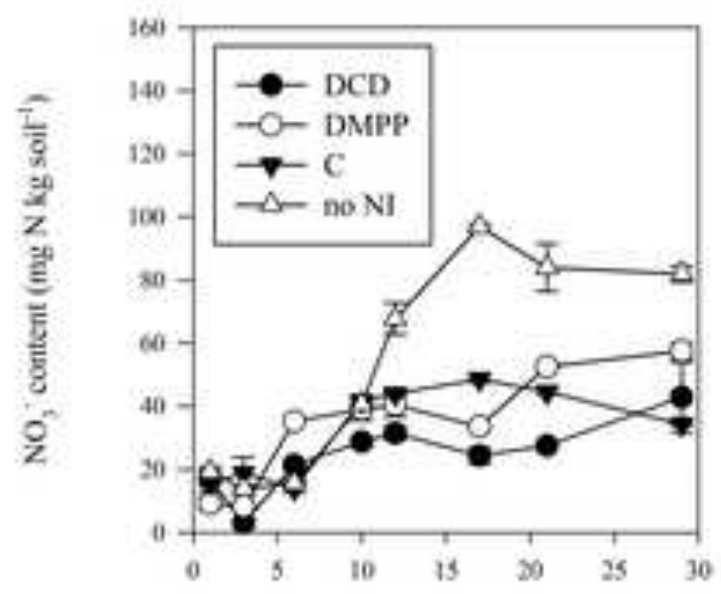

d) $20^{\circ} \mathrm{C}$

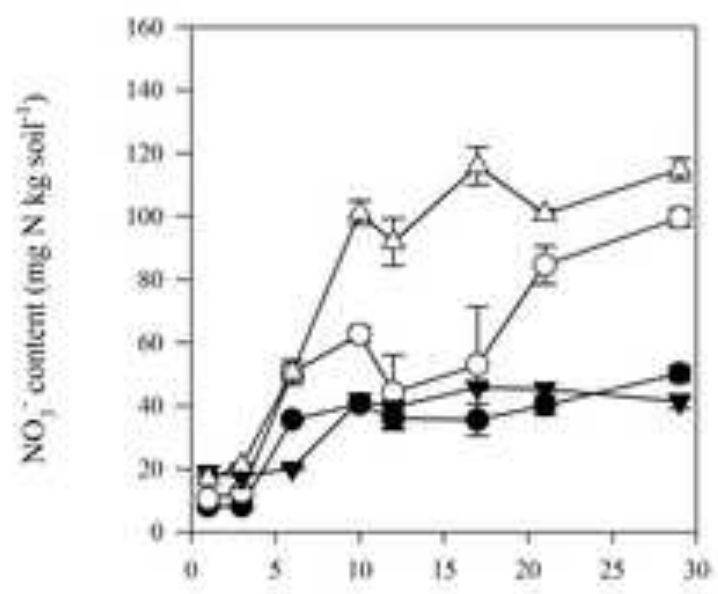

f) $30^{\circ} \mathrm{C}$

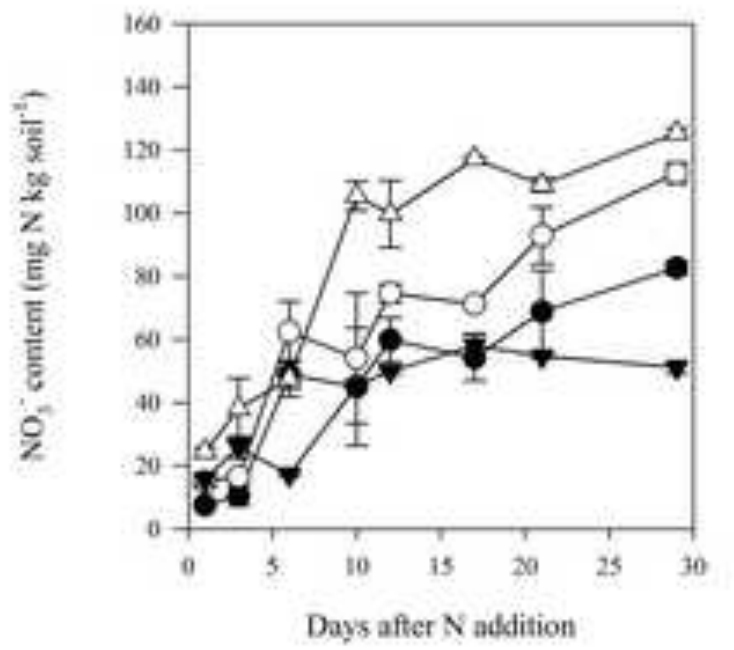


a) $10^{\circ} \mathrm{C}$

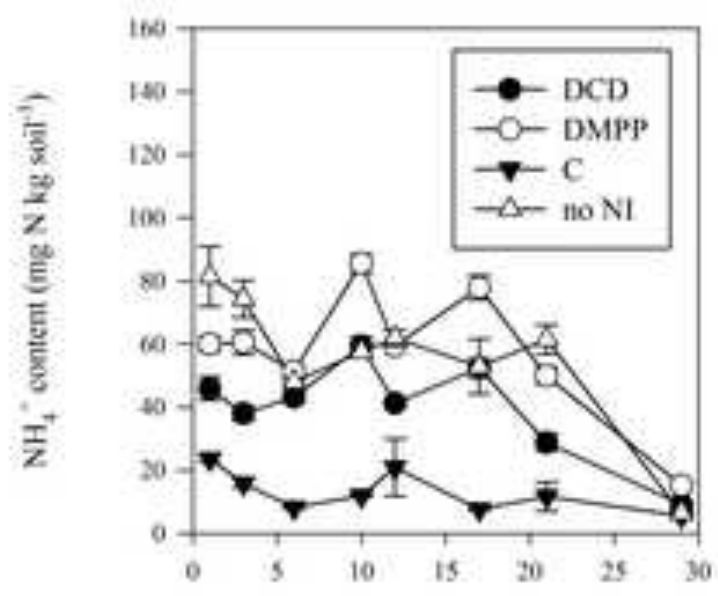

c) $20^{\circ} \mathrm{C}$

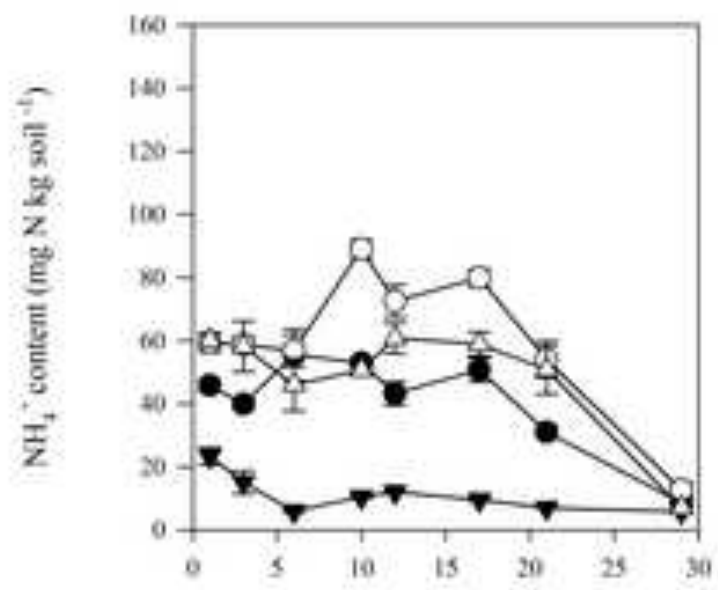

c) $30^{\circ} \mathrm{C}$

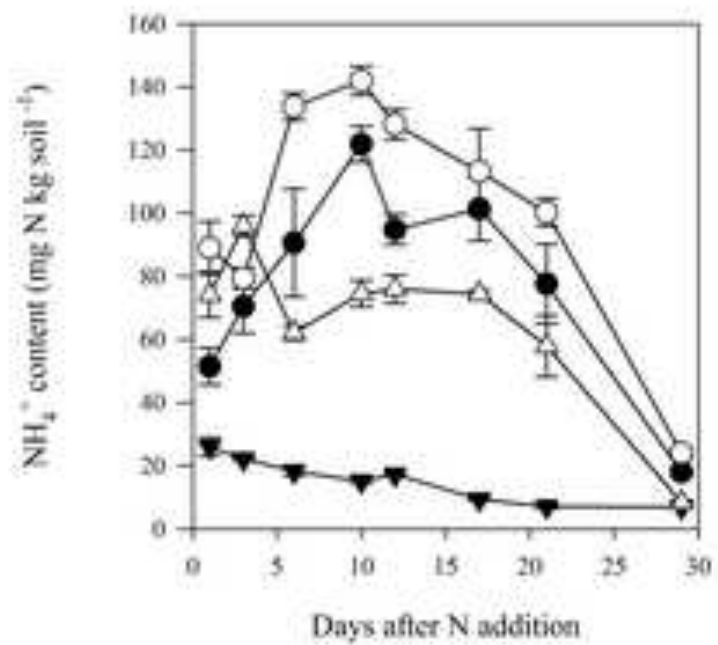

b) $10^{\circ} \mathrm{C}$

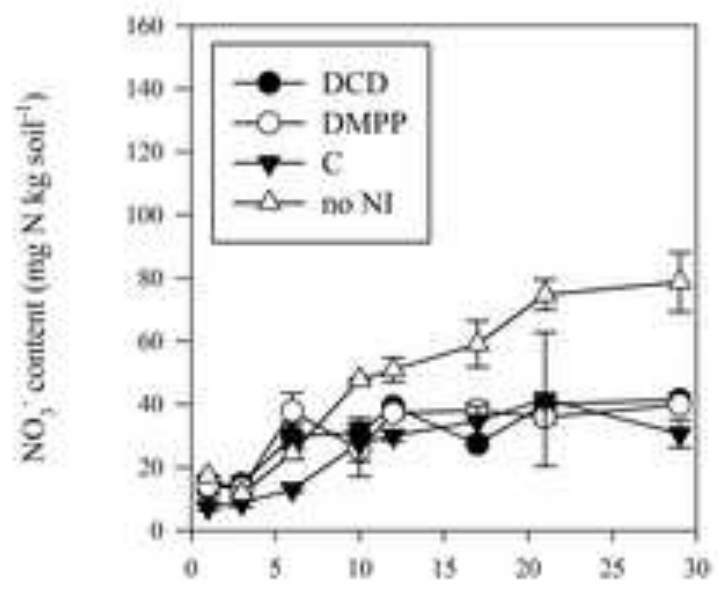

d) $20^{\circ} \mathrm{C}$

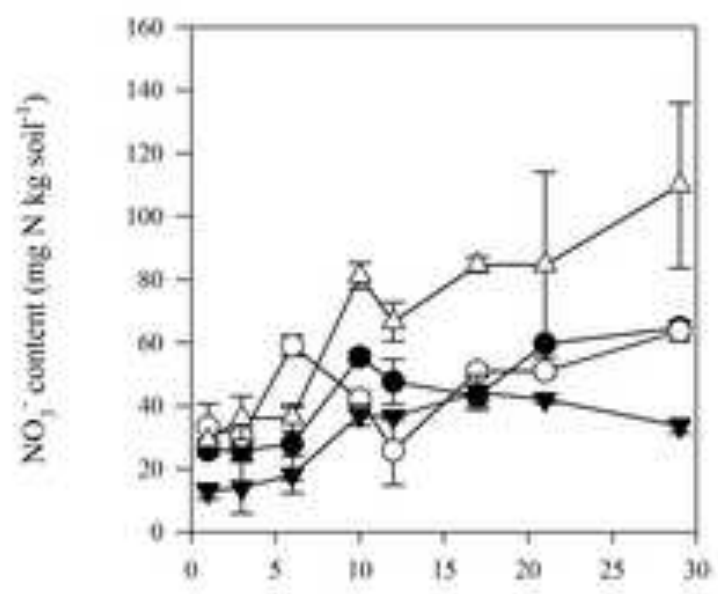

f) $30^{\circ} \mathrm{C}$

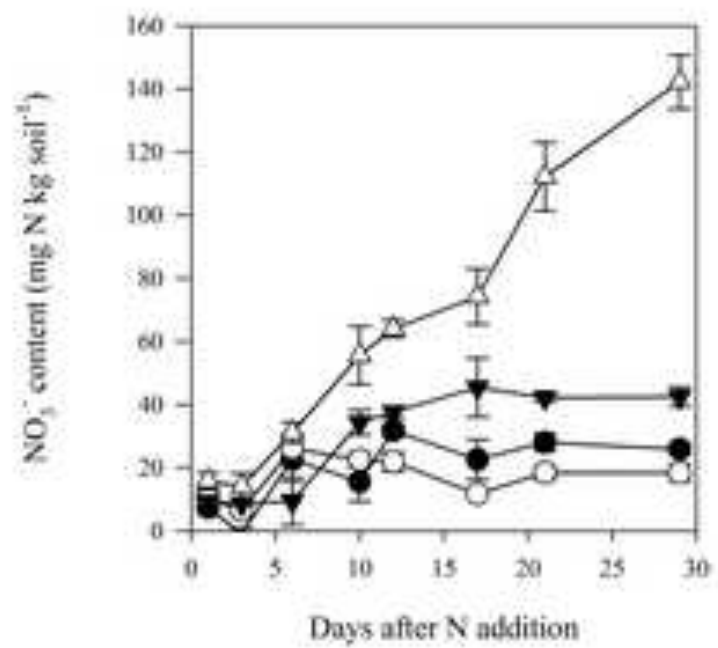


Figure
Click here to download high resolution image

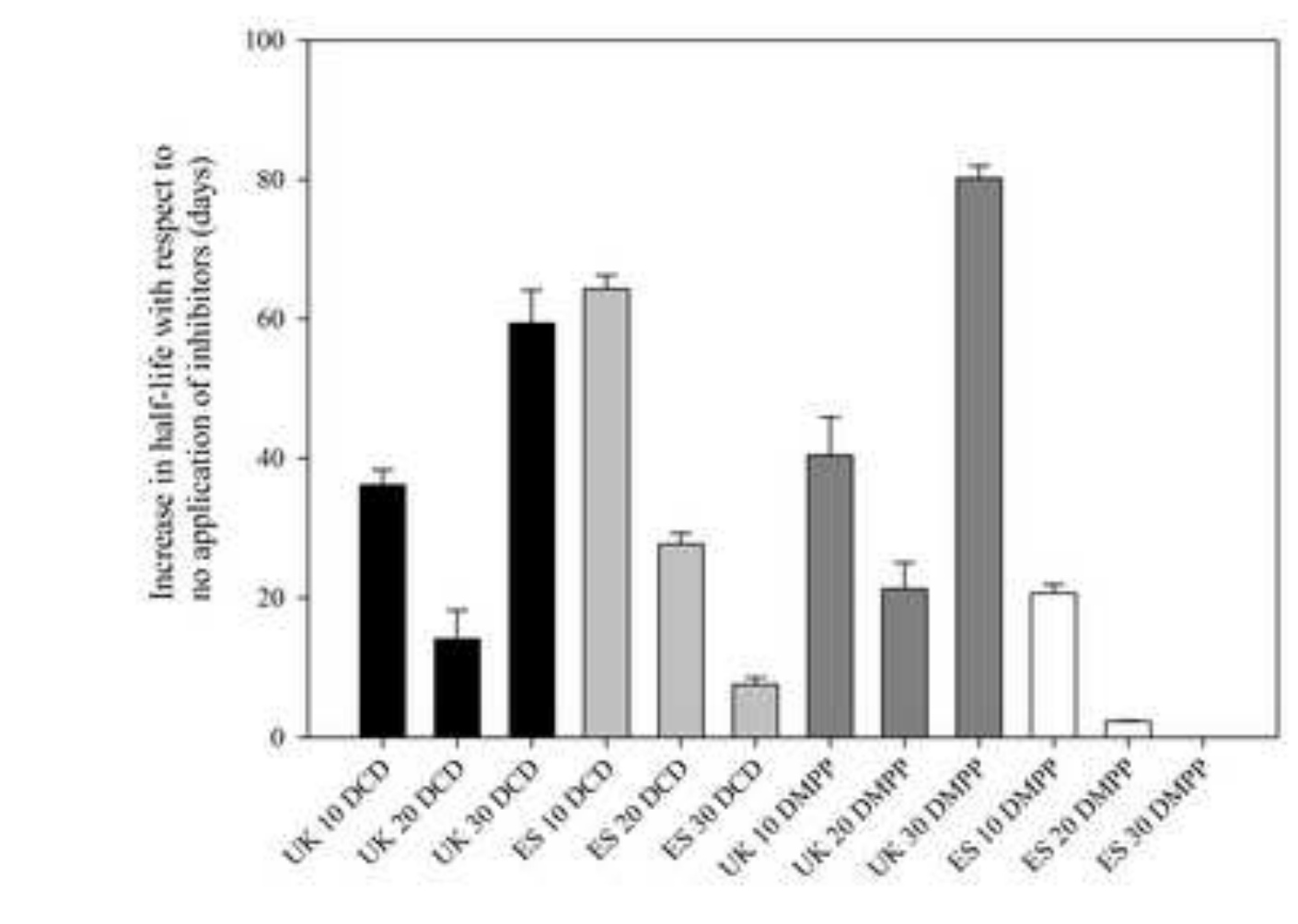

.

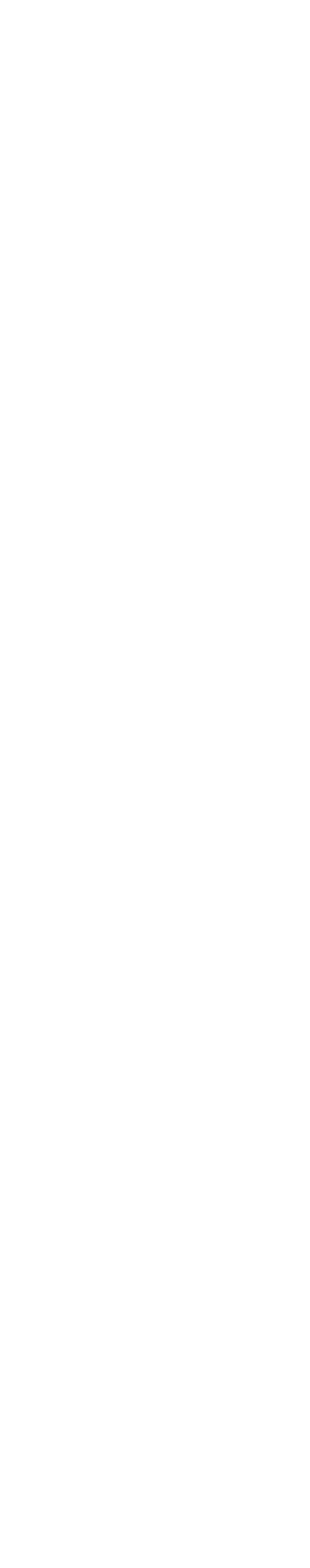
(

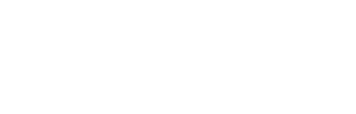
(

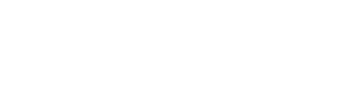

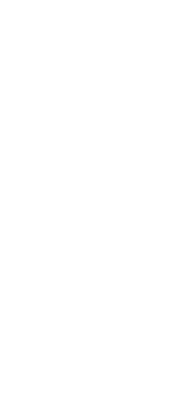


Click here to download Figure: Fig. 6.pdf
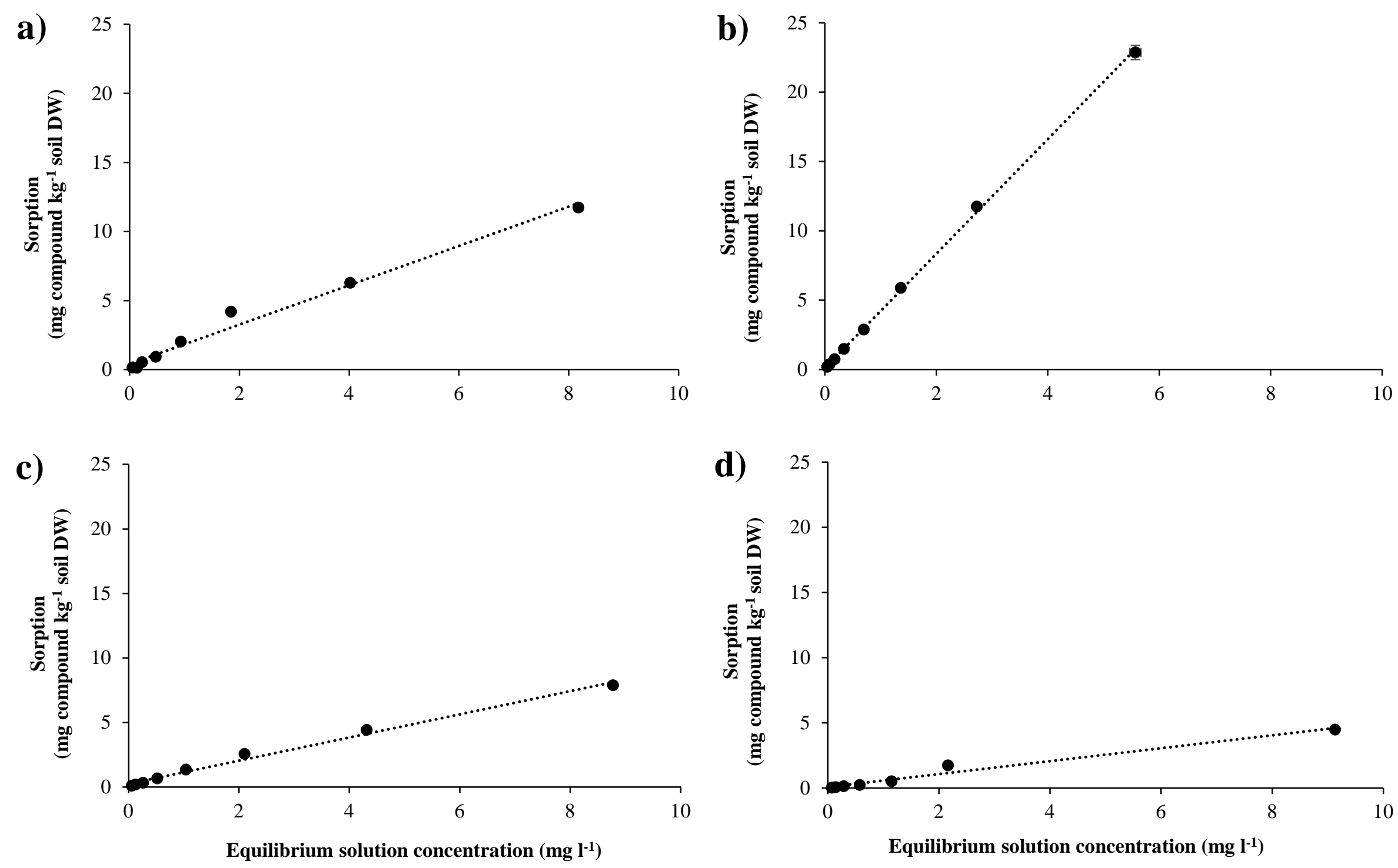

Supplementary material for on-line publication only
Click here to download Supplementary material for on-line publication only: Table S1.docx

Supplementary material for on-line publication only
Click here to download Supplementary material for on-line publication only: Table S1.docx

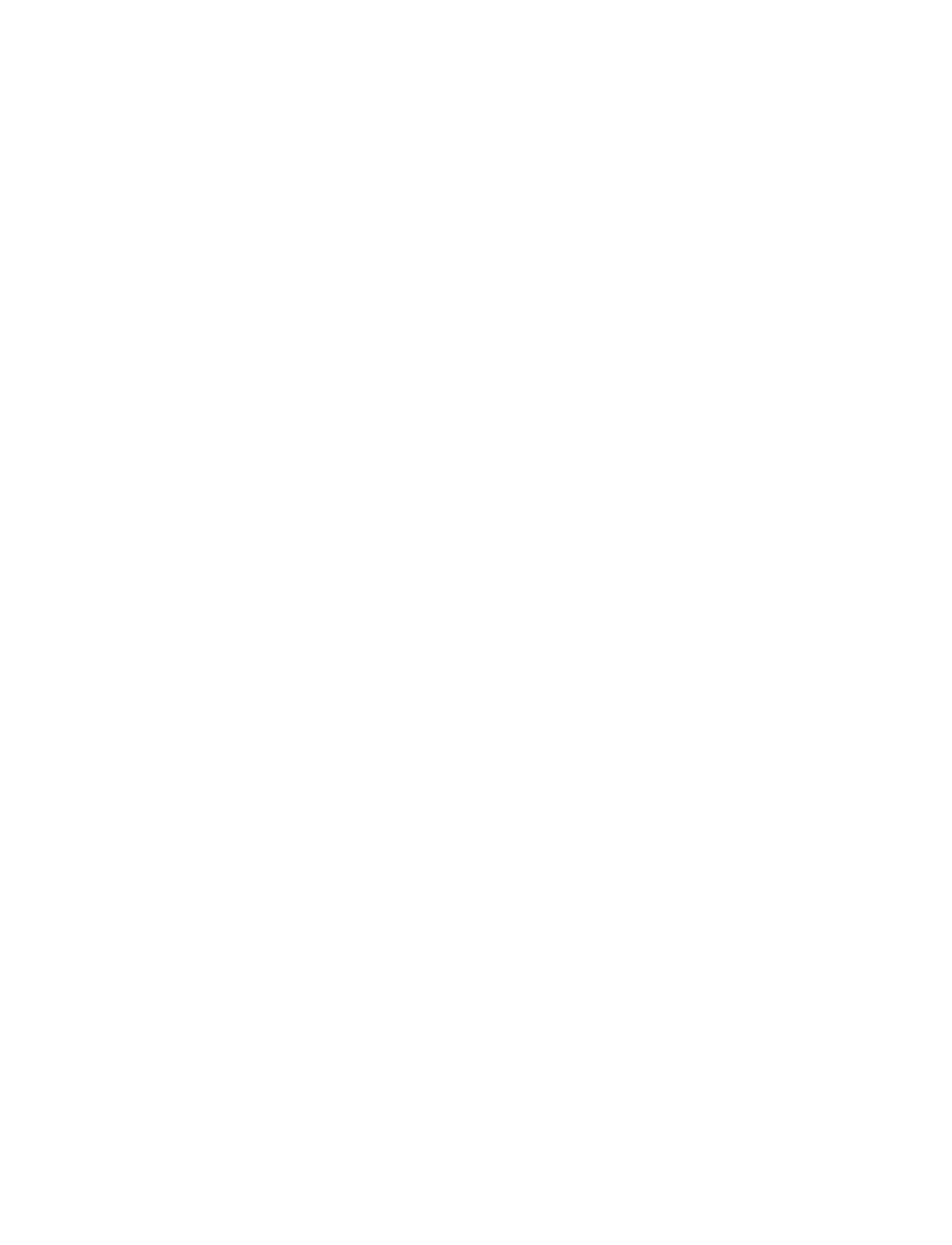


Supplementary material for on-line publication only
Click here to download Supplementary material for

Click here to download Supplementary material for on-line publication only: Table S2.docx 